Organisation de Coopération et de Développement Économiques

Organisation for Economic Co-operation and Development

ECONOMICS DEPARTMENT

English - Or. English

\title{
RAISING AND MOBILISING SKILLS TO BOOST PRODUCTIVITY AND INCLUSIVENESS IN BELGIUM
}

ECONOMICS DEPARTMENT WORKING PAPERS No. 1452

By Vincent Vandenberghe, Lilas Demmou and Manav Frohde

OECD Working Papers should not be reported as representing the official views of the OECD or of its member countries. The opinions expressed and arguments employed are those of the author(s).

Authorised for publication by Alvaro Pereira, Director, Country Studies Branch, Economics Department.

All Economics Department Working Papers are available at www.oecd.org/eco/workingpapers.

This document, as well as any data and map included herein, are without prejudice to the status of or sovereignty over any territory, to the delimitation of international frontiers and boundaries and to the name of any territory, city or area. 
OECD Working Papers should not be reported as representing the official views of the OECD or of its member countries. The opinions expressed and arguments employed are those of the author(s).

Working Papers describe preliminary results or research in progress by the author(s) and are published to stimulate discussion on a broad range of issues on which the OECD works.

Comments on Working Papers are welcomed, and may be sent to the Economics Department, OECD, 2 rue André-Pascal, 75775 Paris Cedex 16, France.

All Economics Department Working Papers are available at www.oecd.org/eco/workingpapers.

This document and any map included herein are without prejudice to the status of or sovereignty over any territory, to the delimitation of international frontiers and boundaries and to the name of any territory, city or area.

The statistical data for Israel are supplied by and under the responsibility of the relevant Israeli authorities. The use of such data by the OECD is without prejudice to the status of the Golan Heights, East Jerusalem and Israeli settlements in the West Bank under the terms of international law.

\section{(C) OECD (2017)}

You can copy, download or print OECD content for your own use, and you can include excerpts from OECD publications, databases and multimedia products in your own documents, presentations, blogs, websites and teaching materials, provided that suitable acknowledgment of OECD as source and copyright owner is given. All requests for commercial use and translation rights should be submitted to rights@oecd.org 


\section{ABSTRACT/RÉSUMÉ}

\section{Raising and mobilising skills to boost productivity and inclusiveness in Belgium}

A highly educated and skilled workforce has been an important driver of productivity performance and prosperity in Belgium. This paper examines skills policies that could help improve productivity and inclusiveness. An increased focus on lifelong learning, improved and more flexible working conditions for older workers, and a more efficient allocation of students and skills would benefit productivity growth. Improving inclusiveness requires increasing access and participation in tertiary education, especially for students with disadvantaged backgrounds. Digitalisation holds the promise of large gains in labour productivity, but is disrupting the nature of employment relationships. It calls for measures that encourage information and communication technology (ICT) upskilling and for adapting tax and benefit systems to the rise of on-demand jobs linked to the use of e-platforms.

This Working Paper relates to the 2017 OECD Economic Survey of Belgium (www.oecd.org/eco/surveys/economic-survey-belgium.htm).

JEL Classification: I2, J24, J26, J40

Keywords: Belgium, human capital, tertiary education, lifelong learning, equity in education, integration policies, labour market participation of seniors, digitalisation, on-demand jobs

\section{Améliorer et mobiliser les compétences pour renforcer la productivité et l'inclusivité en Belgique}

Le niveau élevé de qualification et de compétence de la main d'œuvre a été un élément déterminant de la productivité et de la prospérité en Belgique. Ce chapitre examine les politiques de compétence qui pourraient aider à accroitre la productivité et l'inclusivité. L'accroissement de la productivité nécessite la mise en place de cadres d'action en faveur des salariés seniors pour encourager leur participation à la formation continue, améliorer leurs conditions de travail et tenir compte de leurs besoins en matière d'aménagement du travail qui leur permettaient de rester plus longtemps sur le marché de l'emploi.. La mise en place d'institutions visant à favoriser une répartition plus efficiente des élèves et des compétences concourra également à soutenir la productivité. Pour améliorer l’inclusivité, la Belgique doit développer l'accès et la participation à l'enseignement supérieur, notamment pour les élèves issus de milieux défavorisés. La numérisation offre d'immenses possibilités d'accroître la productivité du travail, mais pertube les relations de travail. Elle appelle des mesures qui encouragent le renforcement des compétences en TIC et l'adaptation des régimes d'imposition et de prestations sociales à la progression des emplois à la demande liés à l'utilisation de plateforme numérique.

Ce Document de travail se rapporte à l'Etude économique de l'OCDE de la Belgique 2017 (www.oecd.org/fr/eco/etudes/etude-economique-Belgique.htm).

Classification JEL: I2, J24, J26, J40

Mots-clés: Belgique, éducation supérieure, formation continue, équité du système éducatif, politiques d'intégration, participation des travailleurs âgés au marché du travail, digitalisation, emplois à la demande 


\section{TABLE OF CONTENTS}

Introduction $\quad 6$

$\begin{array}{ll}\text { Making the most of an ageing society } & 6\end{array}$

Challenges ahead: strengthening inclusiveness and productivity of seniors $\quad 6$

Supporting productivity and jobs of seniors $\quad 8$

Preserving Belgium's advantage in education $\quad 11$

Educational attainment is high $\quad 12$

Improving compulsory education outcomes $\quad 15$

$\begin{array}{ll}\text { Raising resources for tertiary education } & 18\end{array}$

Better matching skills with labour market needs 20

Reallocation of workers to boost productivity 20

Establishing institutions to foster more efficient allocation of students and skills 22

The promises and challenges of digitalisation $\quad 25$

$\begin{array}{ll}\text { REFERENCES } & 29\end{array}$

ANNEX A.1 33

The Hellerstein-Neumark Methodology 33

Results $\quad 35$

$\begin{array}{ll}\text { ANNEX A.2 } & 36\end{array}$

\section{Tables}

1. Early drop-out and unemployment rates 16

2. Changes in the number of students, expenditure on educational institutions and expenditure per student in tertiary education

\section{Figures}

$\begin{array}{lll}\text { 1. The workforce is ageing } & 7\end{array}$

2. The employment rate of senior is comparatively low $\quad 8$

3. Participation in adult education and training is low $\quad 9$

4. Estimated relative wage for seniors are comparatively high in Belgium 11

5. The rise of educational attainment underpins Belgium's prosperity 11

6. The progression of education attainment is slowing down 12

7. Education mismatches remains comparatively moderate 13

8. The return from tertiary education is high in terms of gross wages and time in unemployment 15

9. There is room to improve educational attainment 16

10. Percentage of teachers who report having participated in professional development with content in teaching in multicultural settings 17

11. Share of population aged 25-34 with tertiary education and share of public financing of tertiary education institutions 19

12. Improving allocative efficiency of skills would boost productivity 20

13. There is room to better allocate university-educated workers 22

14. Geographical mobility and workers' reallocation rates 23 
16. Building skills for the future

\section{Boxes}

Box 1. Main barriers to the development of adult education and training (AET) 9

Box 2. Measuring over- and under-education $\quad 14$

Box 3. Main elements of education reforms in the Communities $\quad 18$

Box 4. Skills mismatches 21

Box 5. The productivity of university-educated workers as a function of the distance to the efficiency frontier

Box 6. E-platforms, "alternative" jobs and the need for a relevant legal framework 27

Policy recommendations to raise skills for higher productivity growth and more inclusiveness 28 


\title{
RAISING AND MOBILISING SKILLS TO BOOST PRODUCTIVITY AND INCLUSIVENESS IN BELGIUM
}

\author{
By Vincent Vandenberghe, Lilas Demmou, and Manav Frohde ${ }^{1}$
}

\section{Introduction}

While Belgium has one of the highest productivity levels in the OECD, its growth has dampened markedly in recent years. Productivity gains are important to improve living standards and to help sustain inclusive growth. The determinants of productivity are diverse, and in Belgium two important structural socio-demographic trends, ageing and educational attainment, are at work. They affect productivity by changing the structure of the labour force. Boosting productivity will thus depend on $i$ ) the country's ability to preserve and upskill older workers, whose share of the working age population will increase substantially over the coming decades, ii) the capacity to keep expanding the pool of tertiary-educated workers, who contribute the most to productivity gains, and iii) the use and allocation of skills across firms and industries, especially in the context of digitalisation. Against this background, policies that enhance inclusiveness and productivity are mutually reinforcing. Policy-makers should endeavour to provide framework conditions to allow all individuals to contribute to improved productivity growth through the labour market (OECD, 2016a).

This paper addresses four main questions related to productivity and inclusiveness:

- How to make the most of an ageing workforce, equipping workers with the necessary skills along their careers and avoiding premature exclusion from the labour market.

- How Belgium can maintain its strong performance in education and help people acquire the skills and competences they need to be employable and function well in society.

- How to best use the existing pool of skills, which entails addressing (mis)allocation of skills across firms or industries and the sub-optimal allocation of students among fields of study.

- How digitalisation and automation of tasks are changing the mix of skills needed, as well as the work organisation and the nature of the employment relationship for many of the new ondemand jobs linked to the ever-greater use of e-platforms.

\section{Making the most of an ageing society}

\section{Challenges ahead: strengthening inclusiveness and productivity of seniors}

Belgium's workforce is ageing. The share of workers aged 50 years and above increased from $17 \%$ in 1983 to $27 \%$ in 2015, while the share of workers under 35 years of age decreased from above $49 \%$ to about $33 \%$ over the same period (Figure 1). An important consequence of ageing is that growth will increasingly depend on the economy's ability to generate labour productivity gains. As the share of employed individuals in the total population declines, income per capita will be dragged down unless workers are

1. Vincent Vandenberghe is professor at Université catholique de Louvain and was a consultant for the OECD. Lilas Demmou and Manav Frohde are members of the OECD Economics Department. The paper benefited from consultancy work by Francois Rycx professor of Economics and Université Libres de Bruxelles. The authors would like to thank Piritta Sorsa, Alvaro Pereira and Robert Ford from the OECD Economics Department for valuable discussions and feedback on earlier drafts. The authors would also like to give special thanks to Pedro HerreraGimenez for statistical support and Anthony Bolton, Brigitte Beyeler, Raquel Paramo and Mercedes Burgos for administrative and editorial assistance, all from the OECD Economics Department. 
able to produce more efficiently or the overall employment rate increases. Boosting the employment and productivity of seniors would increase living standards overall and would make society more inclusive.

Figure 1. The workforce is ageing

Share of young (15-34) and older (50-64) workers in total employment.

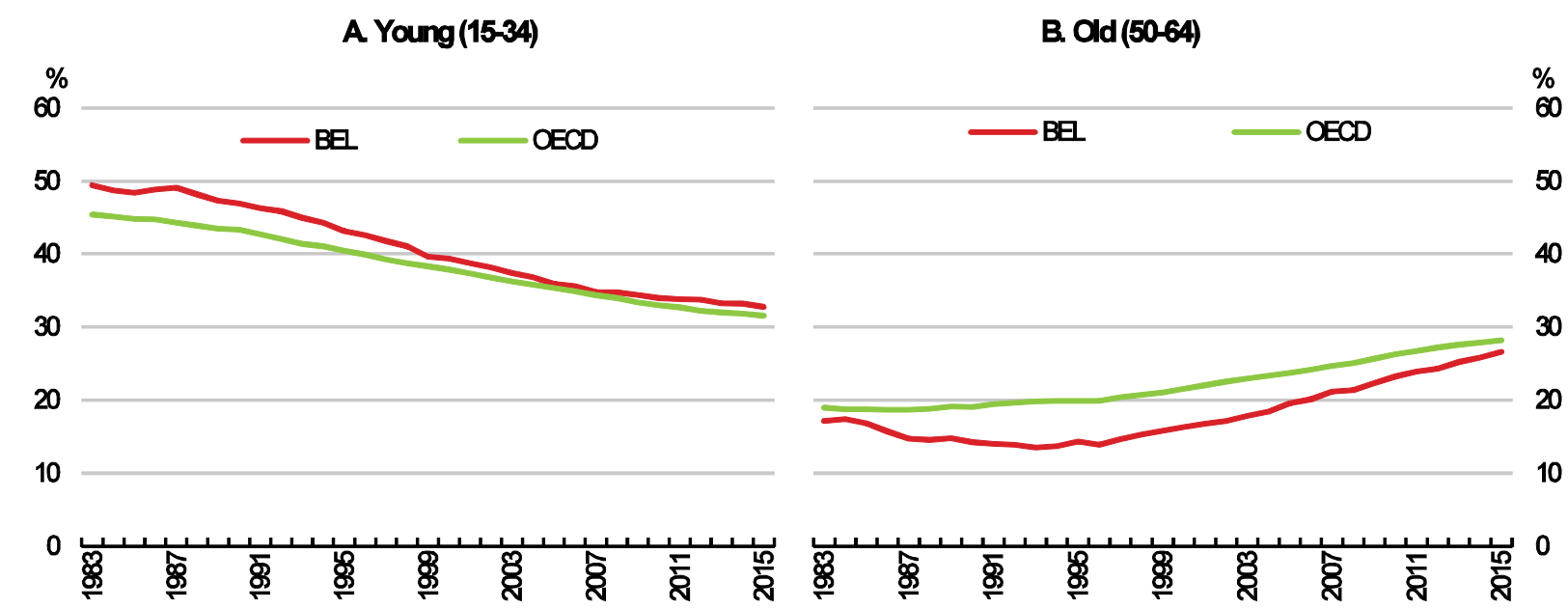

Note: For OECD, data refer to the weighted average 50-64 employment rate of OECD countries for which the 50-64 employment rate is reported since at least 1983 (Australia, Canada, Finland, France, Germany, Ireland, Italy, Japan, Korea, Netherlands, Norway, Portugal, Spain, Sweden and United States). Rates are weighted by the size of overall population for each country.

Source: Source: OECD, Labour force statistics.

Despite increasing over the last two decades, the employment rate of Belgian seniors is among the lowest in the OECD. It is expected to rise as policy-makers continue to reduce possibilities for early retirement, pre-pensions, and long-term sick leave, and increase labour supply by prolonging working life (Figure 2). More proactive policies should also be considered to reduce the risk of seniors being excluded from the labour market. Appropriate measures range from increased focus on lifelong learning to changing work organisation practices. 
Figure 2. The employment rate of seniors is comparatively low

Employment rates of workers aged 55-64, 1983-2015

BE

Men $55-59$

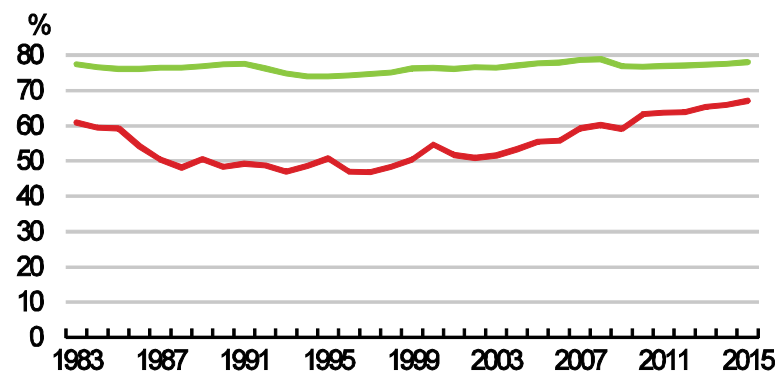

Women 5559

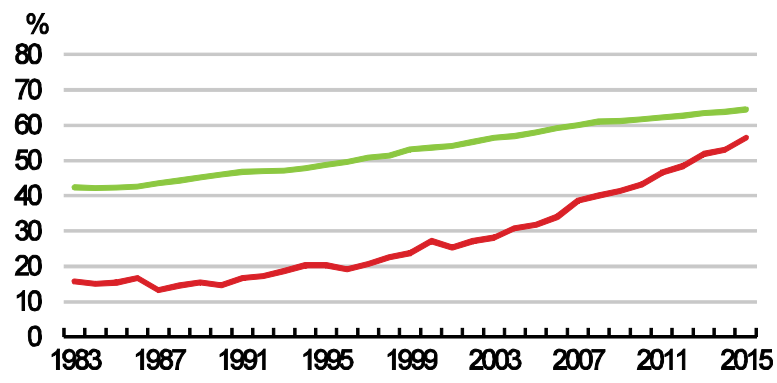

OECD

Men 60-64

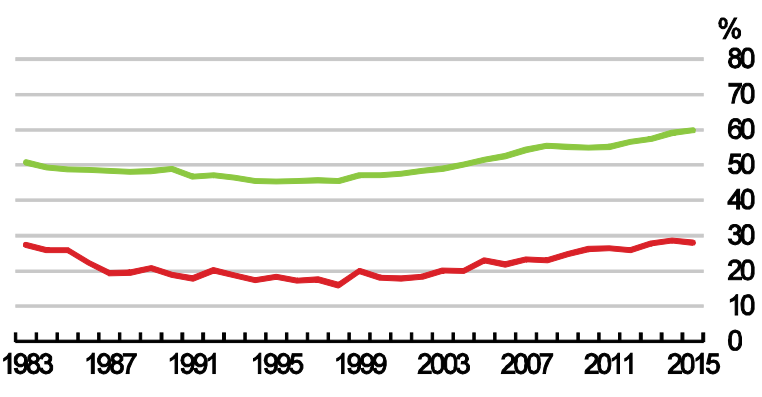

Women $60-64$

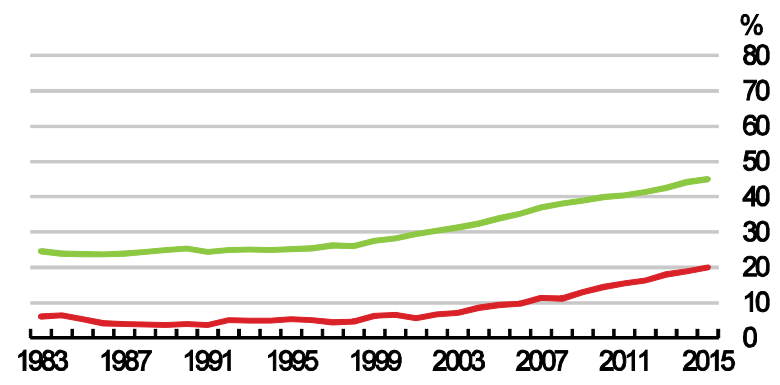

Note: For OECD, data refer to the weighted average 50-64 employment rate of OECD countries for which the 50-64 employment rate is reported since at least 1983 (Australia, Canada, Finland, France, Germany, Ireland, Italy, Japan, Korea, Netherlands, Norway, Portugal, Spain, Sweden and United States). Rates are weighted by the size of overall population for each country.

Source: OECD, Labour force statistics.

\section{Supporting productivity and jobs of seniors}

Maintaining the productivity and employability of older workers calls for more systematic access to adult education and training (AET) as skills needed in a job tend to change during a professional career. Participation in AET was $7 \%$ in 2015, compared to $11 \%$ on average in the EU, with even lower rates for seniors (EC, 2016; Figure 3.A). Several factors may act as barriers to lifelong learning (Box 1). So far, as careers have been of a relatively short duration, in part due to early retirement schemes, the reward from training beyond a certain age has been limited. Employers' incentive to invest in transferable skills is weakened by the risk that other firms may attempt to poach their newly trained workers. If well-enforced the Federal government's decision to oblige firms to provide workers with at least five working days of AET a year as legislated in the recent Werkbaar, Wendbaar Werk (WWW) reform should reduce underinvestment in training. Higher participation could also be achieved by strengthening incentives for training towards shortage occupations, for example by allowing for longer training leave, providing higher subsidies, or by allowing unemployed workers to maintain unemployment benefits during training. 
Figure 3. Participation in adult education and training is low

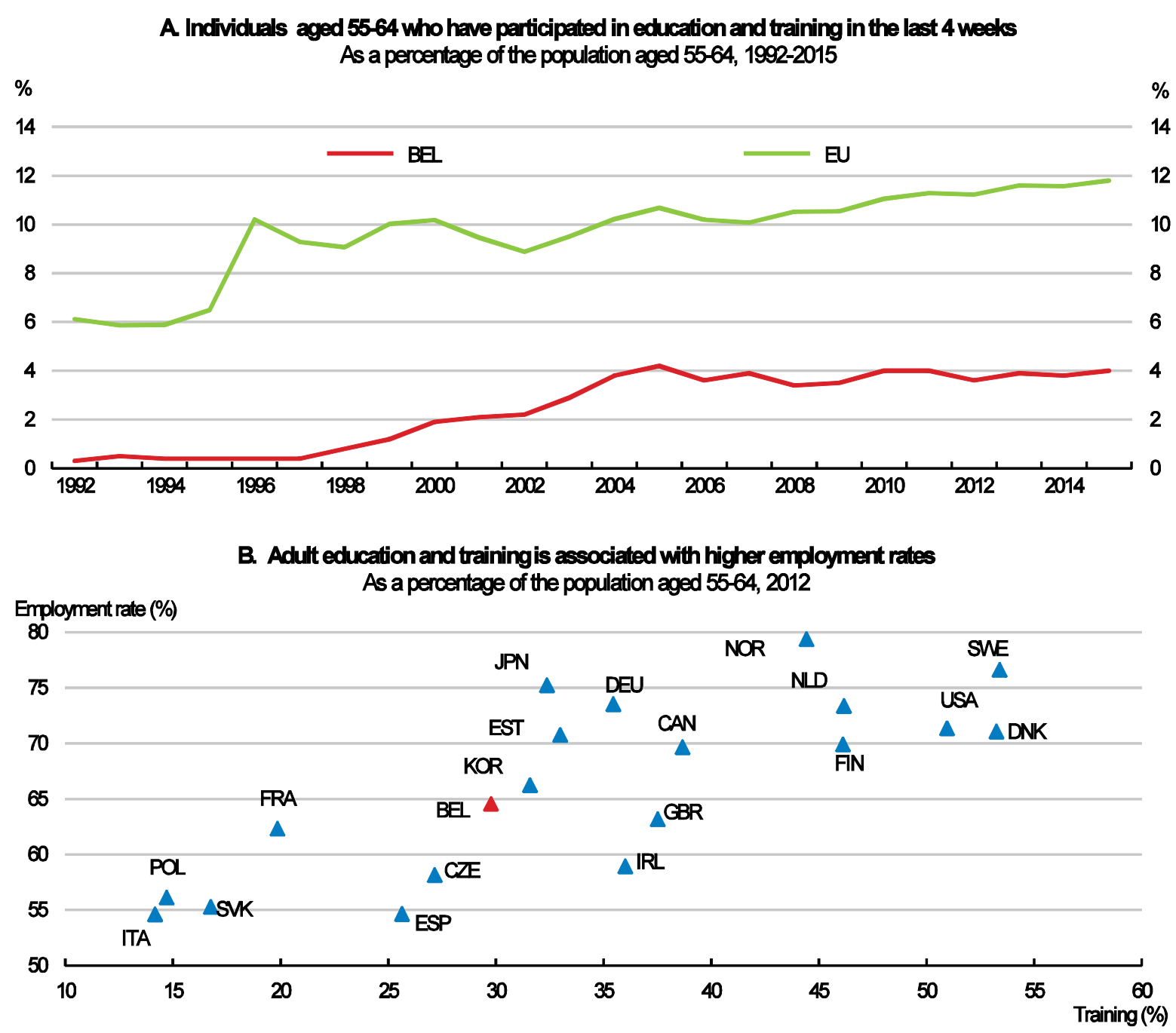

Note: In panel B, training axis refers to participation in training activities over the past year. For Belgium, data refer to Flanders. Source: Eurostat, Labour Force Statistics and; OECD, PIAAC 2013.

Box 1. Main barriers to the development of adult education and training (AET)

- There is compelling evidence that many skills or traits are more readily acquired during childhood than adulthood (Heckman, 2008).

- $\quad$ Financial constraints may be an additional variable as adults generally need the money that only a fulltime job earns to support their family or service their mortgage

- $\quad$ Firms may be reluctant to invest in transferable skills that could be used by competitors (Becker, 1964).

- $\quad$ Shorter careers in Belgium reduce the private return from training.

The lack of a training culture has also been highlighted as an important explanation for the low participation of workers in lifelong learning. European surveys on training show that workers often fail to 
see the advantages of training (AET, 2011). Providing more information on the returns from training would strengthen incentives to engage in lifelong learning. The Flemish Community has opened support centres to provide guidance and counselling services to adults (GOAL, 2016). The Flemish government will also launch a new scheme in 2017 to help workers retrain or reorient themselves towards different professional careers. The French-speaking Community runs information campaigns and has established a service for guidance to citizens (EC, 2016). Social partners should also play a stronger role by more systematically identifying and disseminating best practices.

Establishing age-friendly organisational structures and working environments could help older workers make the most of their skills (Appannah and Biggs, 2015). Existing federal measures targeted at older workers, like the obligation for every firm with more than 20 workers to implement an employment opportunity plan for older workers (Werkgelegenheidsplannen voor oudere werknemers), or the financial help provided by the regions to accommodate the needs of older workers, should be evaluated and, if appropriate, amplified.

More systematically generalising ergonomic workplaces would also strengthen productivity and working conditions for seniors. Small changes to the work environment can make a big difference as illustrated by an experiment by BMW which decided to staff one of its production lines with workers of an age likely to be typical at the firm in 2030 (Loch et al., 2010). The firm improved the productivity of this line by introducing 70 relatively small changes, such as new chairs, more comfortable shoes, magnifying lenses and adjustable tables.

Accommodating older workers' needs for flexible working time could also reduce early exit from the labour force (Blanchet et al., 2016). However, authorities should ensure that fewer hours worked are associated with lower labour costs. If flexitime leads to an increase in unit labour costs it is likely to dampen employment growth (Kantarci and Soest, 2008). The federal WWW reform contains interesting ideas, such as annualisation of working time, an extended right to telework, and the portability of paid holidays in case of job changes.

The relatively high labour cost of older workers may also reduce their employability. In many industries labour costs rise mechanically with seniority and beyond a certain point tend to exceed productivity. However, as wages tend to be below productivity in early years of careers these arrangements are inter-temporarily coherent for employers and probably motivate workers to make more effort and remain fully committed (Lazear, 1979; Kirsten and Heywood, 2007). Nevertheless wage profiles appear to be particularly steep in Belgium (Figure 4). In some cases this has contributed to early retirement clauses and job separation many years before the legal retirement age.

The Federal government's General Policy Statement of 2014 contains an explicit and welcome commitment to reduce seniority pay, concomitantly to pension and early retirement reforms. Many steps have already been taken to increase the pension age and to make early retirement less generous and accessible, including as part of the 2015 pension reform. The government could also foster efforts to reduce the steepness of seniority profiles through the well-established wage bargaining process. 
Figure 4. The estimated relative wage for seniors is comparatively high

Wage of male workers aged 60-64 relative to workers aged 30-35, 2012

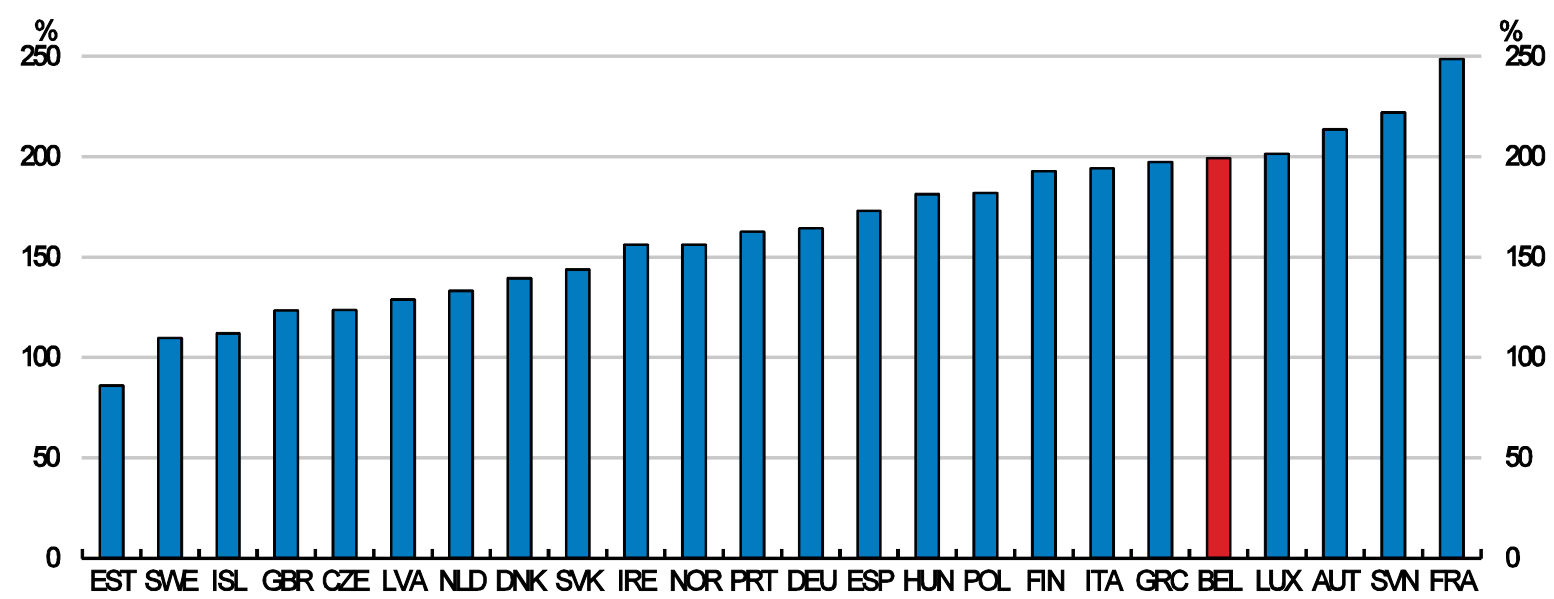

Note: For Belgium, data refer to Flanders. Relative wages are obtained using HECKIT 2-stage estimation, regressing (log) gross hourly wages on age group, controlling for years of schooling, PIAAC scores and occupational status.

Source: Calculations based on PIAAC 2013 database.

\section{Preserving Belgium's advantage in education}

High educational attainment has been an important factor in Belgium's high productivity and prosperity (Figure 5, Lebedinski and Vandenberghe, 2014). International experience suggests that for advanced economies like Belgium, productivity growth depends on the quality of higher education (Aghion et al., 2006, 2009; Vandenberghe, 2017). This underscores the importance of improving access, quality and participation in tertiary education and maintaining its quality.

Figure 5. Belgium's prosperity is underpinned by high educational attainment

Belgium vs. rest of the world, 2014
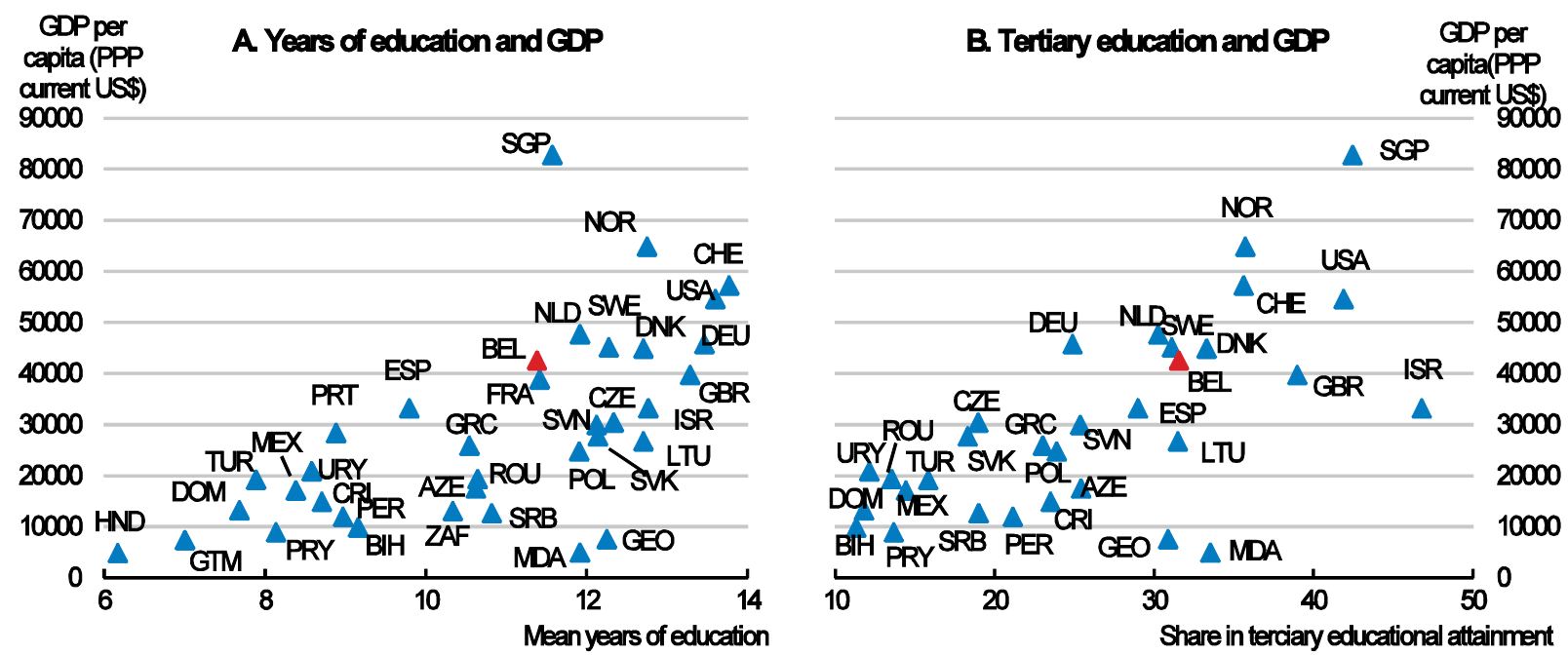

Source: UNESCO database, 2016. 


\section{Educational attainment is high}

Belgium has successfully lifted the educational attainment of its population since the 1950s, but progress has slowed in recent years. Starting from a high level, the increase in tertiary education attainment between 2000 and 2015 has been one of the lowest among OECD countries (Figure 6.A and B), although the number of students enrolling for higher education in Flanders and in Brussels increased markedly in 2015/2016. A catching-up effect does not fully explain the slowdown in the years preceding 2015 as most countries with a higher share of tertiary educated than Belgium in 2000 have had stronger growth rates (Figure 6.C).

Figure 6. The progression of education attainment is slowing down

\section{A. Educational attainment of individuals aged 25 and above Average number of years of education}

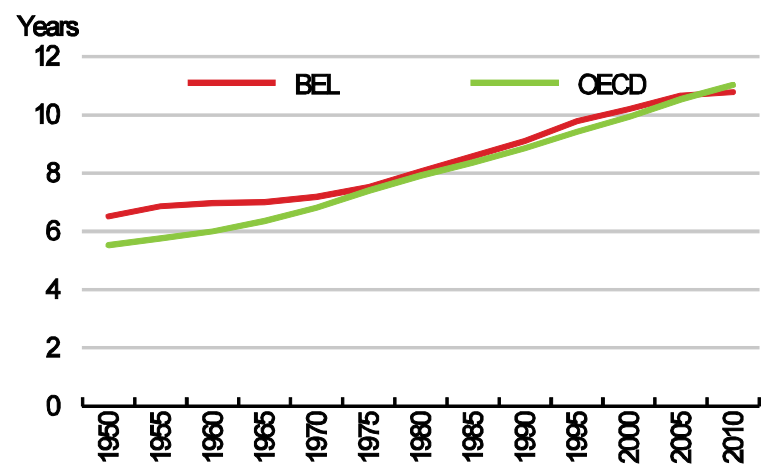

B. Share of individuals aged 25-34 with tertiary education attainment

\section{Growth in share of tertiary ectucated among OECD best performers in $2000^{1}$}

Percentage points offference, 2000-15

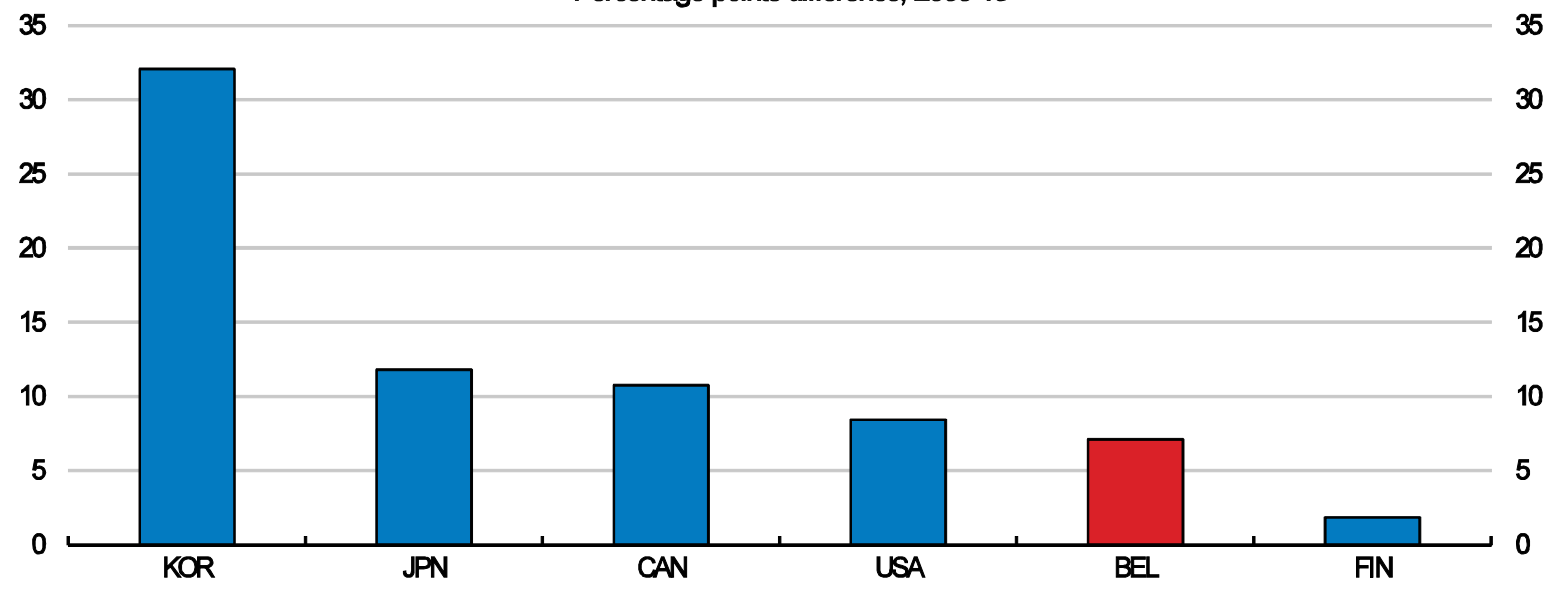

1. Top six countries with highest share of individuals aged 25-34 with tertiary education attainment in 2000.

Source: Barro \& Lee, 2016 and; OECD, Education at a Glance 2016 database.

Education mismatches are moderate. Under-education can have an impact on productivity by mismatching skills and job needs, while over-education points to a misallocation of resources. About $15 \%$ of workers in Belgium were overeducated in 2012 and 10\% under-educated (Figure 7, Box 2). This puts Belgium (Flemish Region) significantly below the OECD average in terms of over-education and slightly above the OECD average for under-education. Other estimates for the Belgian private sector suggest 
somewhat higher figures with about 20\% of workers over-educated and 25\% under-educated (Karakaya et al., 2007; Kampelmann and Rycx, 2012; Giuliano et al., 2017).

Figure 7. Education mismatches remains comparatively moderate

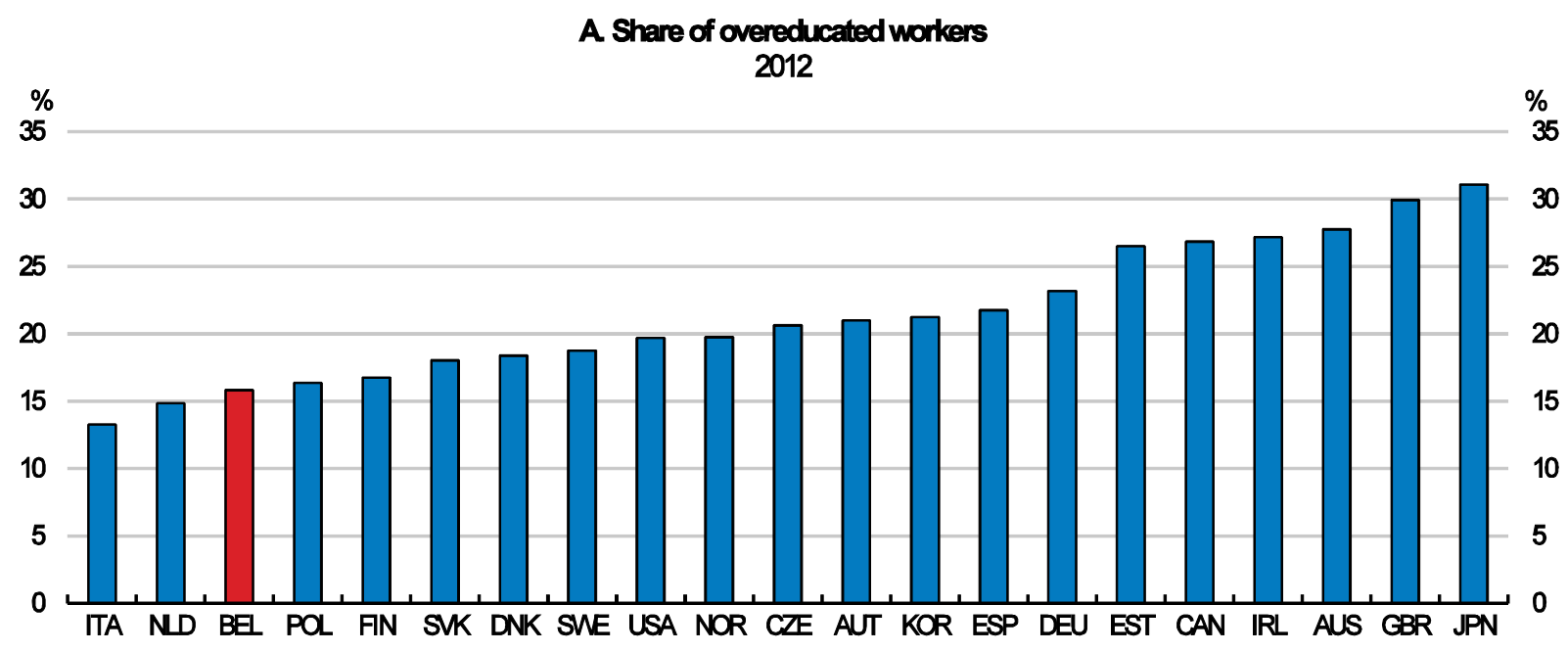

B Share of undereducated workers

2012

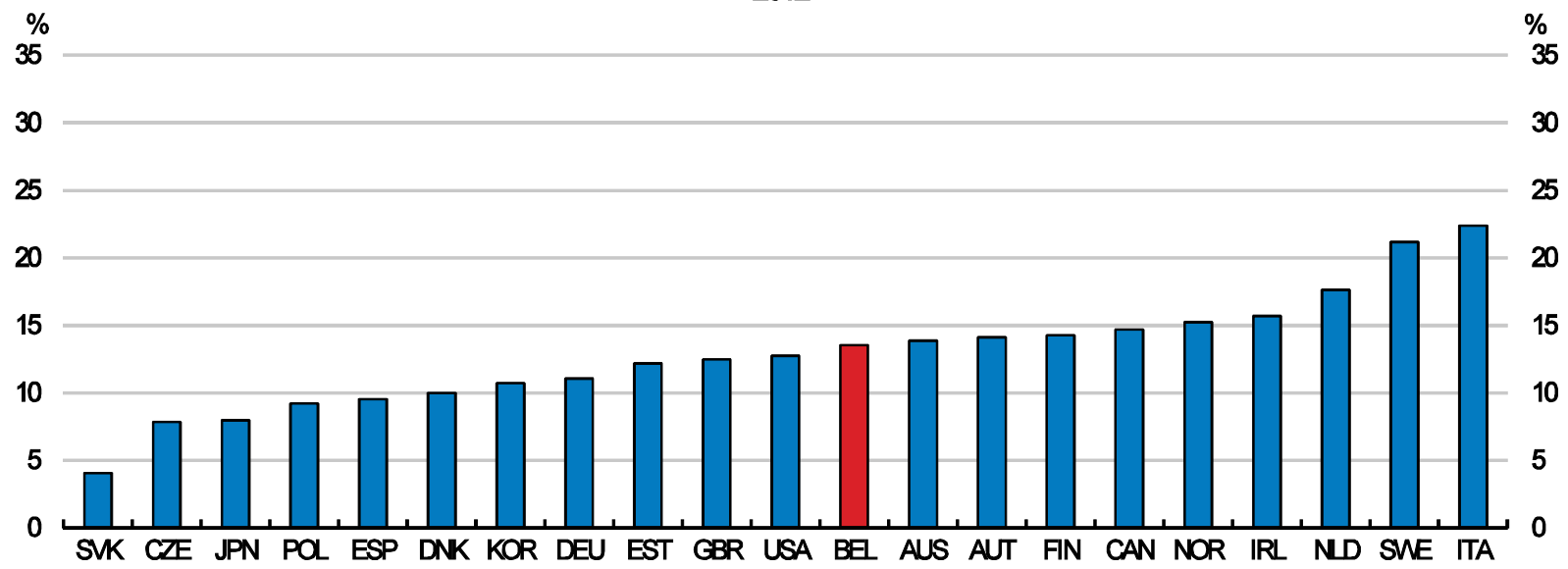

Note: For Belgium, data refer to Flanders. For the United Kingdom, data refer to England and Northern Ireland. Qualification mismatch is defined relative to the qualification needed to get the job, as reported by the respondents. Over-skilled workers are those whose proficiency score is higher than that corresponding to the 95th percentile of self-reported well-matched workers - i.e. workers who neither feel they have the skills to perform a more demanding job nor feel the need of further training in order to be able to perform their current jobs satisfactorily - in their country and occupation. Under-skilled workers are those whose proficiency score is lower than that corresponding to the 5th percentile of self-reported well-matched workers in their country and occupation.

Source: OECD, PIAAC 2013. 


\section{Box 2. Measuring over- and under-education}

\section{What is over-education?}

First highlighted by Freeman (1976), education mismatch has been extensively studied, especially since the late 1980s, to evaluate the consequences of the continued expansion of participation rates in higher education in developed economies.

Over-education occurs when workers are more highly educated than required for their particular job. This may typically happen when educational attainment has risen a lot but firms fail to take advantage of a more highly educated labour force, or simply do not need it to remain productive and profitable. Individuals may then be forced to take jobs for which they are over-educated; something that may be costly to the economy.

\section{Measures of over-education}

There are three ways of measuring educational mismatches. Each method has advantages and disadvantages (for a detailed discussion see Leuven and Oosterbeek, 2011).

- An objective measure or job analysis approach is based on an evaluation by professional analysts of the level and type of education that is required for a specific job. The American Dictionary of Occupational Titles (DOT) takes this approach.

- A subjective or self-assessment approach requires the employee and/or employer to determine the type and level of formal education that is necessary for the achievement of the tasks associated with a given job. This method thus relies on employee and/or employer surveys.

- An empirical or realised matches approach derives the required level of education for a job from what workers in the corresponding job or occupation have usually attained. The required education is then generally computed based on the mode of the education in each occupation.

\section{Over-education and productivity}

Firm level evidence suggests that (over-)education contributes positively to productivity (Rycx et al., 2015). This is especially the case for firms with a high share of high-skilled jobs and in knowledge-based industries (Kampelmann and Rycx, 2012). By contrast, under-education is found to be detrimental to firm productivity, but only among young workers.

The high return on tertiary education suggests that the economy has benefitted from the increased supply of educated workers. Estimates at the firm level suggest that those with a bachelor's degree are $58 \%$, and those with a master's degree 92\%, more productive than workers with at most primary education attainment (see Annex 1). At the individual level, Mincerian wage equations, which relate earnings to educational attainment, show that taking individuals without a degree as a reference, those with a lower secondary degree earn about $10 \%$ more per month (gross). The premium rises incrementally to $64 \%$ for university graduates (Figure 8.A). Similar equations relating the level of education to the risk of unemployment confirm the premium for tertiary educated students: the risk of unemployment is $59 \%$ higher for someone with at most a primary degree compared to someone with a university degree (Figure 8.B). 
Figure 8. The return from tertiary education is high in terms of gross wages and time in unemployment

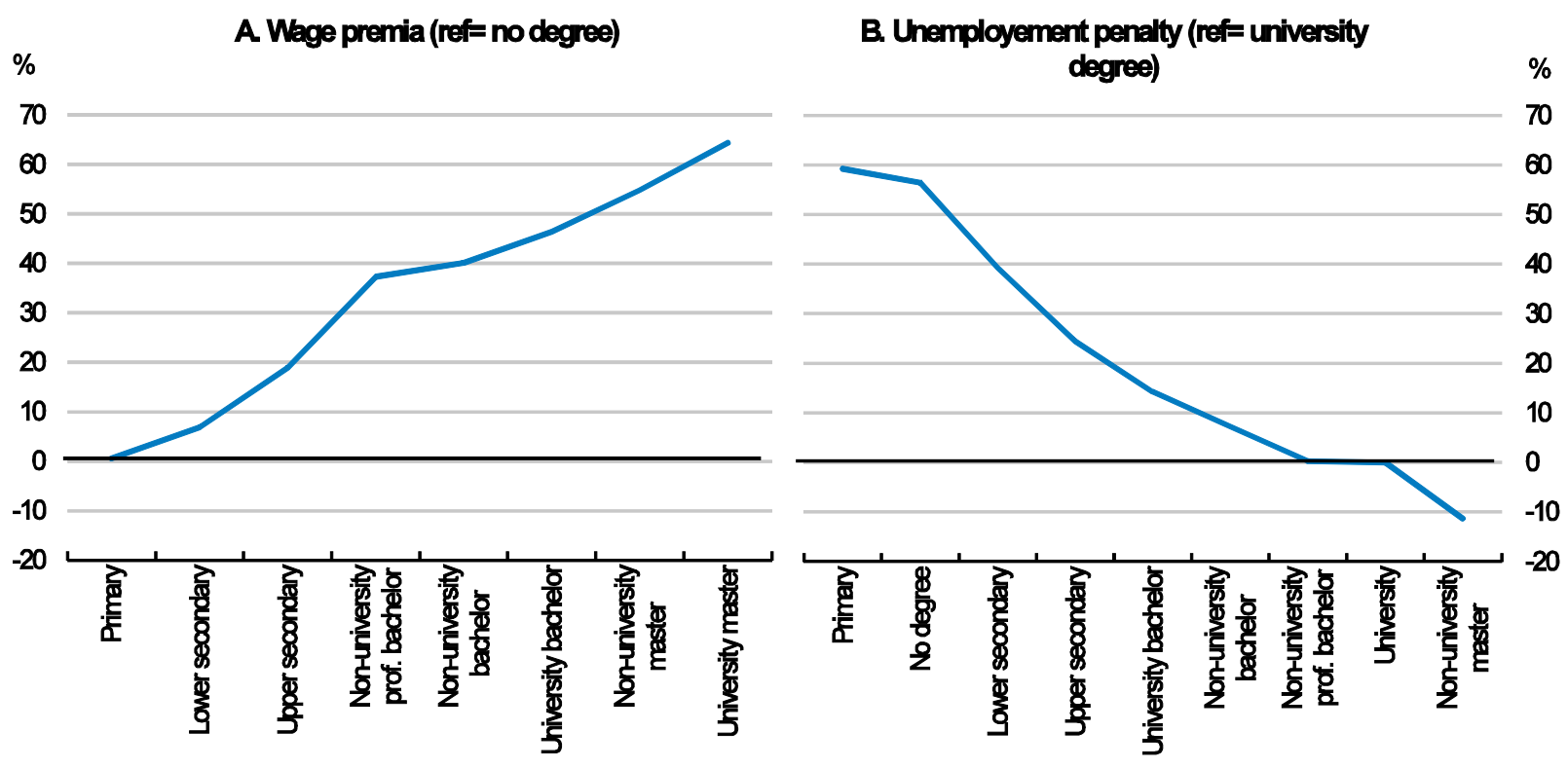

Note: Marginal effect of degree, conditional on age, age2 and gender

Source: Vacature, 2008, 2010 and 2012.

The still high returns to tertiary education, and moderate education mismatches suggest that further expanding the pool of tertiary-educated individuals further would raise productivity. However, given the slow rise in attainment in recent years this is likely to prove challenging. The lower progression in tertiary education attainment in part stems from poor performance at lower levels of education.

\section{Improving compulsory education outcomes}

Too many youth do not successfully complete upper-secondary education. This means that, in spite of liberal admission rules, they cannot undertake tertiary education. Socio-economically disadvantage individuals and first and second generation immigrants are particularly at risk. Youth living in areas with high unemployment rates, are over-represented among early school leavers (Table 1). In addition, PISA results indicate that the score gap between native born students and those with an immigrant background are among the largest in the OECD, although this is not true for all the Belgian regions. As a result, youth with an immigrant background are only $65 \%$ as likely to obtain a tertiary degree as their native peers; near the lowest ratio in the OECD (Figure 9). 
Table 1 Early drop-out and unemployment rates, 2015

\begin{tabular}{|lcc}
\hline & Early drop-out rate & Unemployment rate \\
\hline Whole country & 18 & 8.5 \\
\hline Brussels & 26 & 17 \\
\hline Flanders & 15 & 5 \\
\hline Antwerpen & 15 & 6 \\
\hline Limburg & 15 & 6 \\
\hline Oost-Vlaanderen & 16 & 4 \\
\hline Vlaams-Brabant & 12 & 5 \\
\hline West-Vlaanderen & 15 & 4 \\
\hline Wallonia & 22 & 12 \\
\hline Brabant Wallon & 11 & 8 \\
\hline Hainaut & 25 & 13 \\
\hline Liège & 24 & 13 \\
\hline Luxembourg & 23 & 9 \\
\hline Namur & 15 & 11 \\
\hline
\end{tabular}

Note: Early drop-out rate refers to the share of 30-34 without upper-secondary education Source: Eurostat

Figure 9. There is room to improve educational attainment

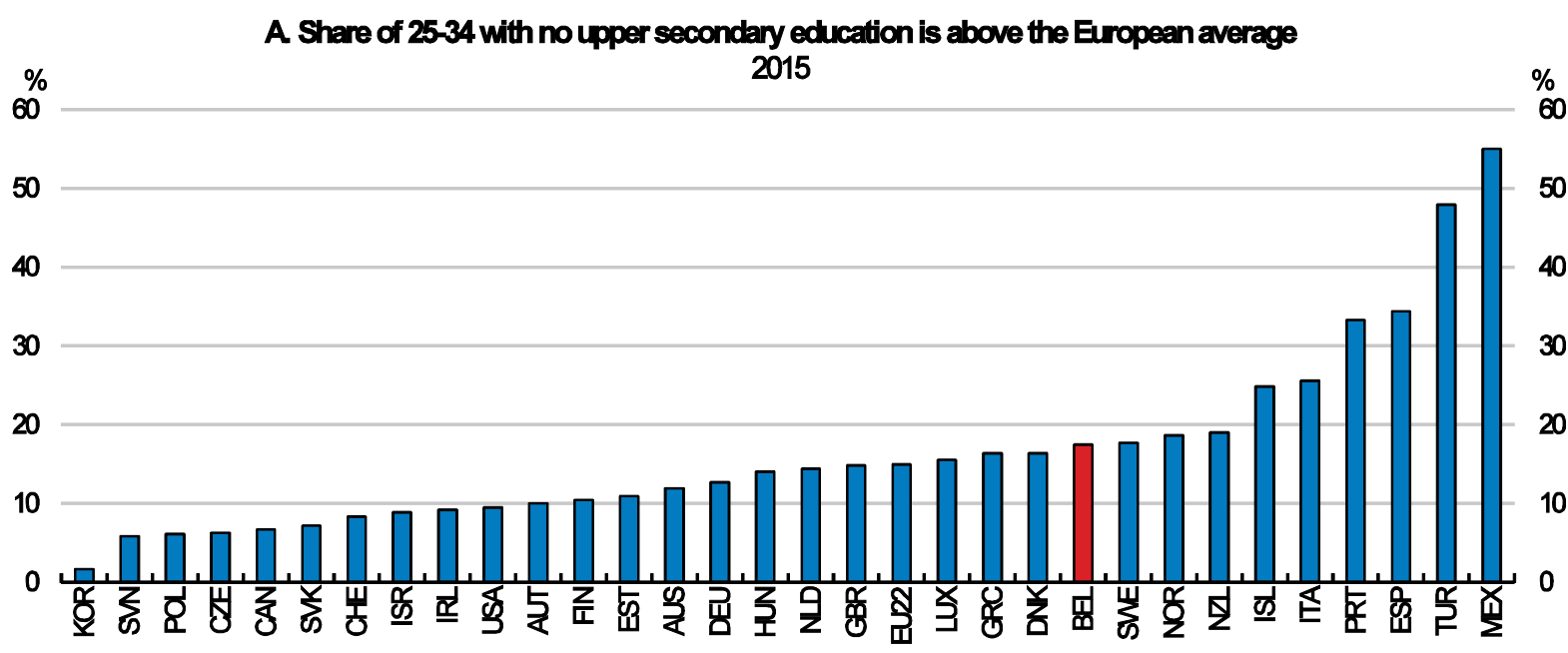

B. The educational attainment of immigrants is lower

2nd generation immigrants with tertiary education per nonimmigrant with tertiary education, aged 25-34, 2012

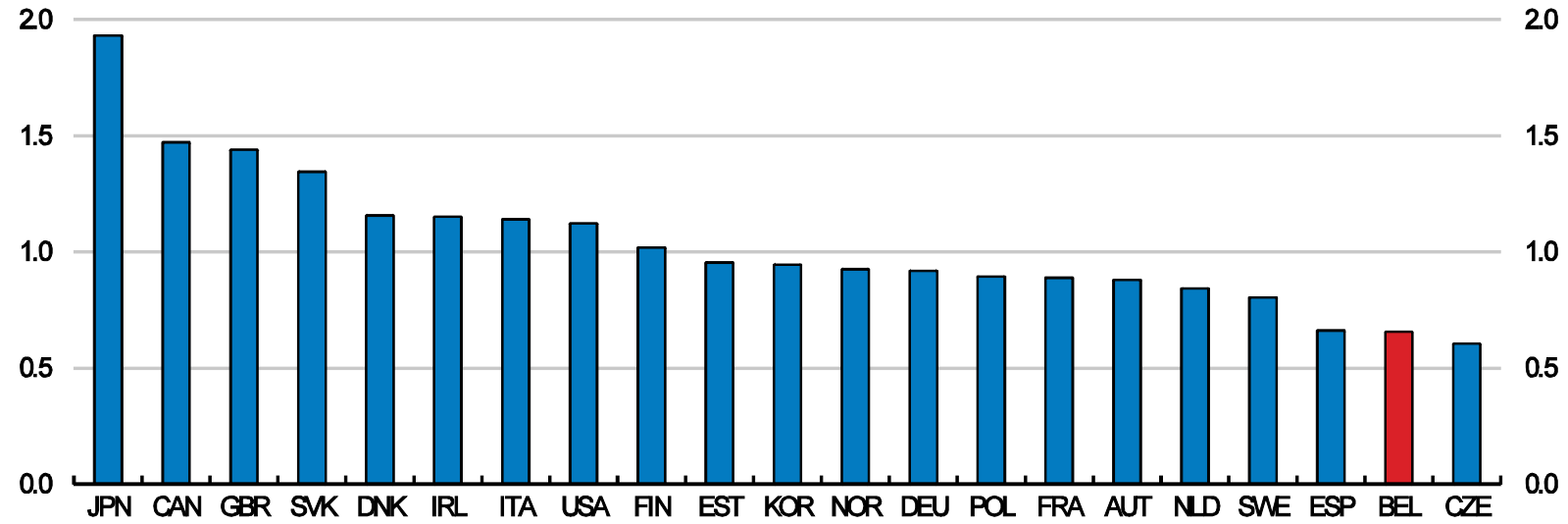

Note: In panel $B$, a value of 1 corresponds to equality. For Belgium, data refer to Flanders.

Source: OECD, Education at a Glance 2016 and; OECD, PIAAC 2013. 
The authorities from the three communities have implemented major education reforms in order to improve educational outcomes for socio-economically disadvantaged students (Box 3; EC, 2016). Some issues require specific attention:

- Both the Flemish and the French Communities have enacted policies aimed at reducing socio-economic segregation. A closer evaluation of the effectiveness of these polices is needed.

- More should be done to ensure that socio-economically disadvantaged pupils are taught by more qualified and experienced teachers. The existing uniform pay structure prevents policymakers from using teacher pay to achieve this goal. Existing efforts to improve the quality of schools where disadvantaged pupils are over-represented, by attracting and retaining effective teachers could be made more effective by developing incentives schemes.

- According to the OECD Teaching and Learning International Survey (OECD, 2013c), which was only conducted in the Flemish Community, teachers have comparatively less training in teaching in multicultural settings than teachers in the majority of OECD countries (Figure 10).

- In Flanders spending per student is higher in secondary than elementary education despite evidence that the rate of return on investment in human capital is greatest in the earlier years of school (Nusche et al., 2015).

Figure 10. Percentage of teachers who report having participated in professional development with content in teaching in multicultural settings

Percentage of teachers, 2013

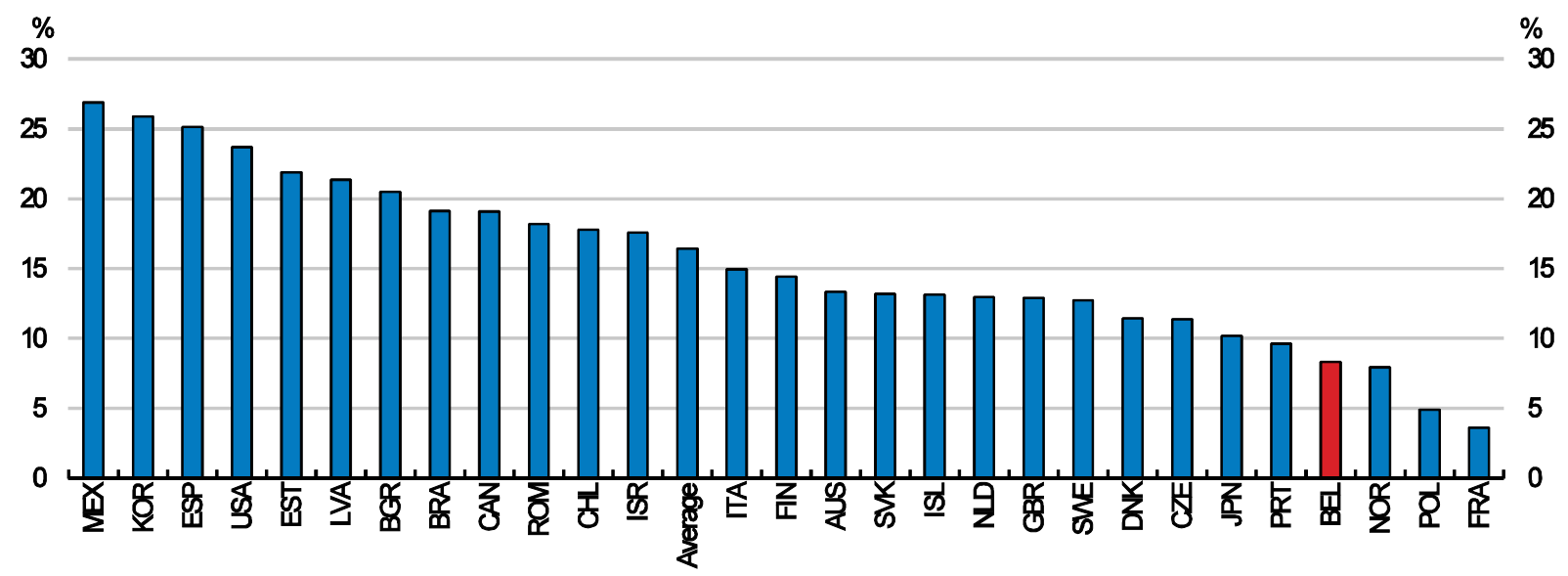

Note: For Belgium, data refer to Flanders. For Canada, data refer to Alberta. For the United Kingdom, data refer to England. Percentage of lower secondary education teachers who report having participated in professional development on teaching in a multicultural or multilingual setting in the 12 months prior to the survey.

Source: OECD, TALIS 2013 Database. 


\section{Box 3. Main elements of education reforms in the Communities}

Both the French and Flemish Communities are engaged in major school reforms aimed at providing more inclusive education and reducing dropouts. Both communities are currently revising their enrolment policies. Government agreements for 2014-2019 refer to the need to realise a better repartition of experienced teachers to schools with many disadvantaged pupils (EC, 2016).

\section{Flemish Community}

In early 2016 the Flemish government approved a revised concept note on the new integrated early school leaving approach, including an action plan. A concept note containing proposed measures for raising the profile of new entrants to teacher education programmes and streamlining of programmes and quality enhancement of teacher training has also been adopted. Some measures have already been implemented, such as the introduction of a (non-binding) entrance test for students at the beginning of initial teacher training offered by university colleges. Other planned reforms include the introduction of a specific master's in education. A draft decree is planned in early 2017 in view of finalising the reform by 2020 . In May, 2016 the government agreed on two concept notes on modernising secondary education. Plans include measures to increase guidance for pupils, to provide more options courses for pupils who do not hold a primary certificate, and to reorganise the structure of educational offers.

\section{French Community}

The French Community is currently rolling out its reform programme of compulsory education Pacte pour un Enseignement d'Excellence, 2015-2025. The reform will grant individual schools and teachers greater autonomy. Heads of underperforming schools will be required to draw up plans to tackle low achievement, onthe-job teacher training will be made more relevant to the school, and teachers made more equipped for social, cultural and pedagogical diversity. The pathway from the elementary to the lower secondary level will be streamlined and initial vocational education and training will be simplified by reducing the number of tracks and integrating apprenticeships into the education system. An increase in the course length for initial teacher training from the current level of three years is also under consideration. However, budget constraints likely rule out opting for a five-year master's for all teachers (EC, 2016).

Source: EC, 2016, Education and Training Monitor 2016, Belgium, European Commission; French Community; Flemish Community.

\section{Raising resources for tertiary education}

Education quality may have been affected by a decline in per-student spending in tertiary education (Table 2). First, more severe budgetary constraints -high public debt, increasing pension and health care costs - make it intrinsically more difficult for the state to invest in human capital. Second, Belgium's geographical location at the heart of Europe coupled with its comparatively liberal admission rules, has contributed to an increase in non-resident students from EU countries with restricted access to studies in certain academic fields in their own national higher education system. These students rarely enter the Belgian labour market upon completion of their studies (Gérard and Vandenberghe, 2007).

Table 2 Changes in the number of students, expenditure on educational institutions and expenditure per student in tertiary education, in \% (2008-2013)

\begin{tabular}{lccc}
\hline & $\begin{array}{c}\text { Change in } \\
\text { expenditure }\end{array}$ & $\begin{array}{c}\text { Change in the number } \\
\text { of (full time) students }\end{array}$ & $\begin{array}{c}\text { Change in expenditure } \\
\text { per student }\end{array}$ \\
\hline EU & 11 & 7 & 6 \\
OECD & 17 & 11 & 5.5 \\
Belgium & 15 & 18 & -3 \\
\hline
\end{tabular}

Source: OECD, 2016c. 
The level of tuition fees in Belgium depends on a student's financial situation, the type of qualification (regulated for initial programmes, free for most advanced/executive programmes) and whether or not the student is an EU national. In the French Community around $70 \%$ of students in public or government-dependent private higher education institutions pay the maximum fee of EUR 836 per academic year. In the Flemish Community 77\% of students in initial bachelor's and master's programmes pay the maximum fee of EUR 890, while in the German-speaking Community nearly all students pay EUR 450 (EC, 2015). In Germany students do not pay tuition fees. In France fees are generally fixed at around EUR 400 a year for an undergraduate degree and EUR 470 for a master's degree, although around one third of students are exempt from fees. At certain schools and for certain subjects fees are higher and may reach up to EUR 10000 per year. In the Netherlands all students pay fees of EUR1 951 per year.

Against a background of high public debt and significant fiscal constraints some OECD countries have chosen to increase tuition fees to sustain spending on tertiary education. For instance, tuition fees were increased in England in 2011, which markedly increased overall spending on tertiary education. Despite an initial decline, the participation rate in higher education has continued to increase (Department for Education, 2016). The Belgian authorities could consider increasing tuition fees in tertiary education while maintaining the grant and waiver system to support disadvantaged students. Granting loans with repayment contingent on the level of their future income would help compensate graduates who have not achieved wage gains from their studies.

Figure 11. Share of population aged 25-34 years with tertiary education and share of public financing of tertiary education institutions

A Shere of 25-34 with tertiary education attainment

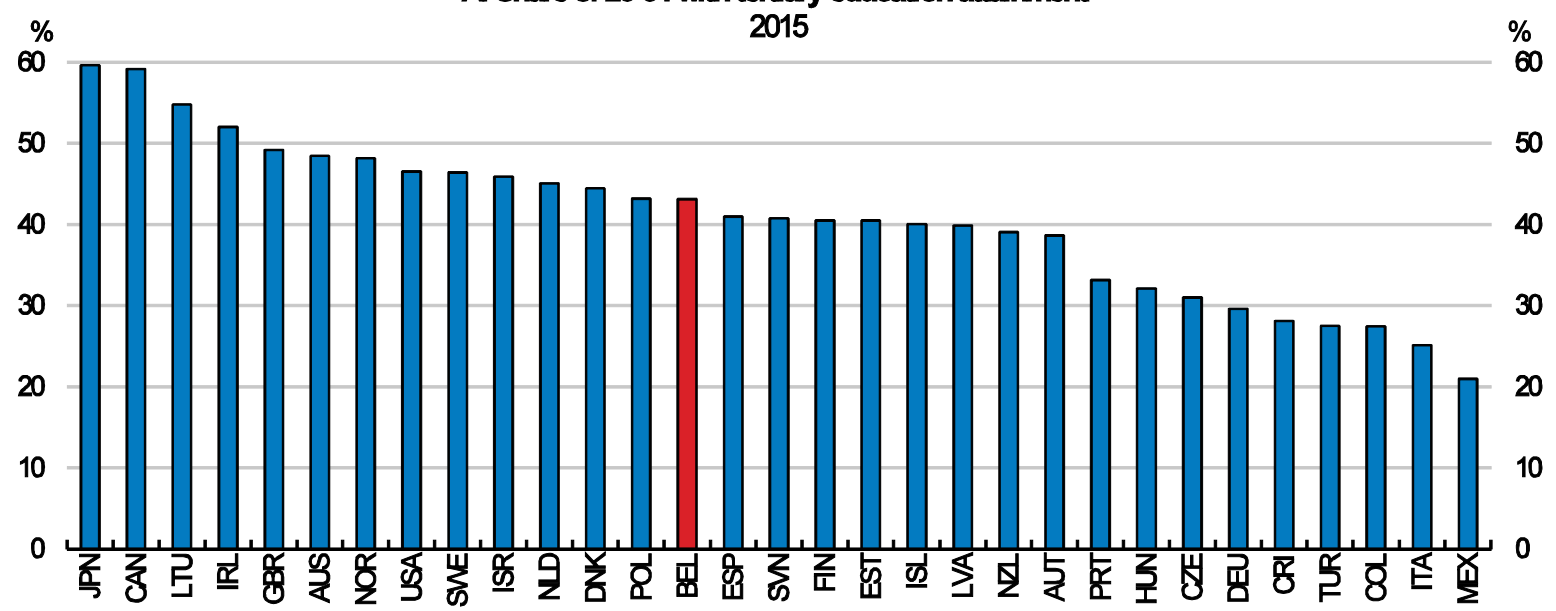

B. Share of public financing of tertiary ectucation institutions

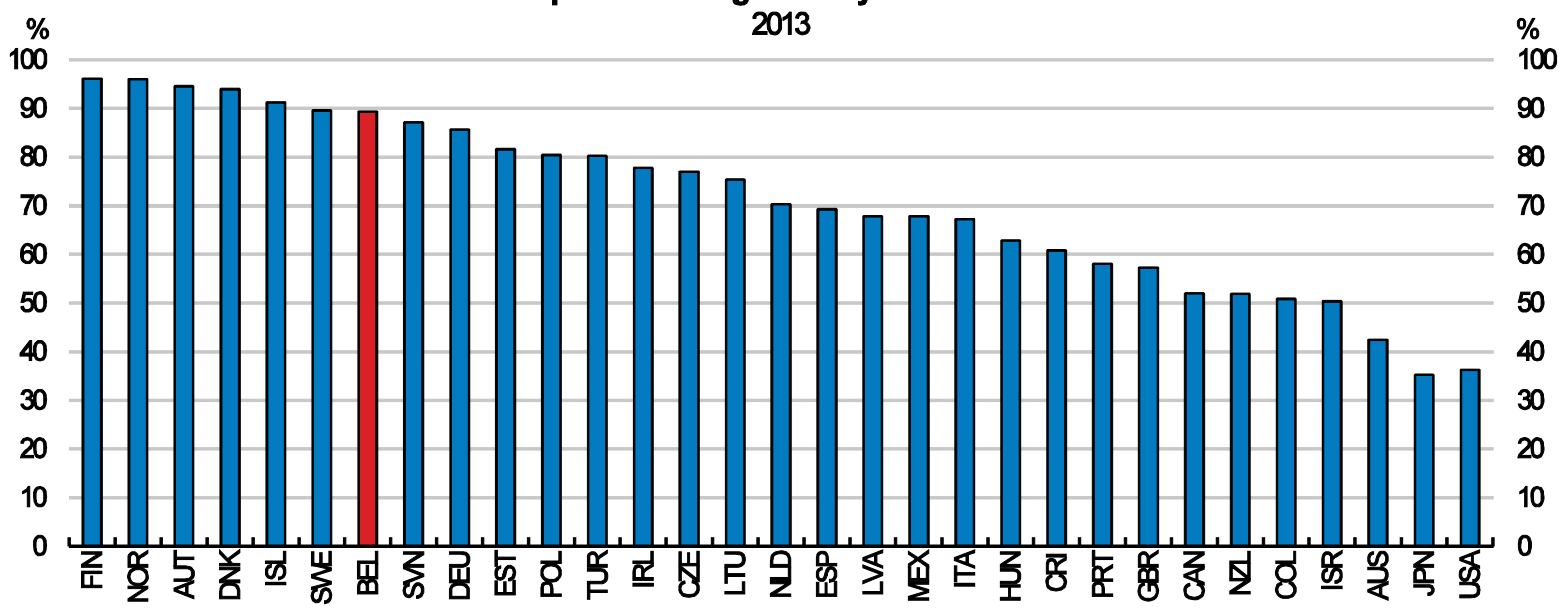

Source: OECD, Labour Force Statistics 2016; and OECD, Education at a Glance 2016. 


\section{Better matching skills with labour market needs}

\section{Reallocation of workers to boost productivity}

Although over-educated workers contribute positively to the productivity of their current employer (as discussed above) this does not entail that workers are employed where they would be the most productive. Many firms find it difficult to attract those workers who they would employ more productively (Andrews and Cingano, 2014). According to PIAAC micro-data productivity in Belgium (Flanders) is negatively affected by skills mismatches at both the aggregate and the sector level (Box 4). Reducing skills mismatches to the lowest level of the OECD would lead to an estimated economy-wide productivity gain of 3\% (Adalet and Andrews, 2015; Figure 12).

Figure 12. Improving allocative efficiency of skills would boost productivity

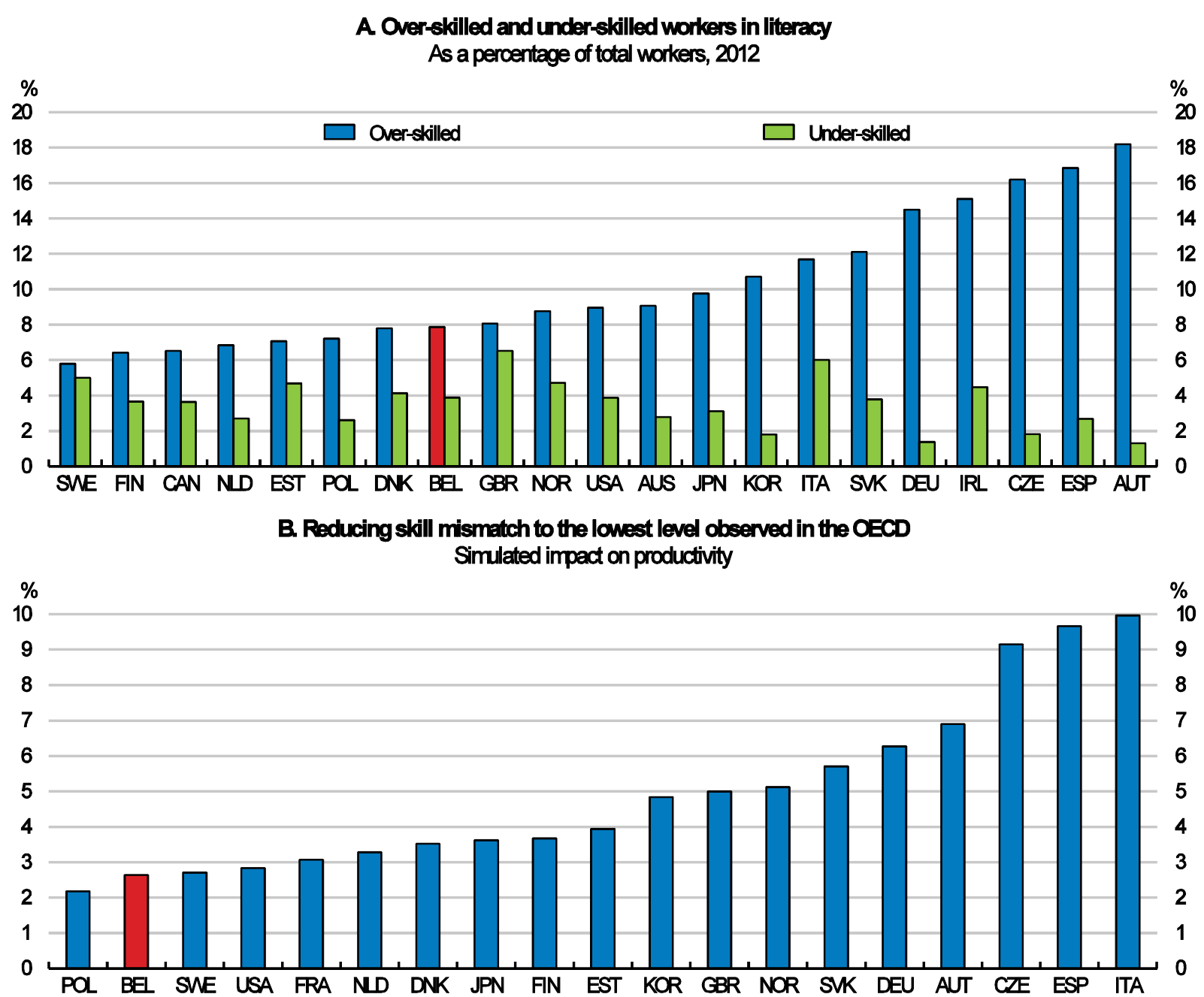

Note: Panel B shows the difference between the actual allocative efficiency and a counterfactual allocative efficiency based on lowering the skill mismatch in each country to the best practice level of mismatch. Both the actual and counterfactual numbers are calculated by aggregating 1-digit industry level mismatch indicators using a common set of weights based on the industry employment shares for the United States. For example, lowering the skill mismatch to best practice leads to a simulated gain of around $10 \%$ in Italy and $3 \%$ in the United States.

Source: OECD, PIAAC 2013 and; Adalet, M. and D. Andrews, 2015. 


\section{Box 4. Skills mismatches}

Occupational mismatch can be measured through educational mismatches (see Box 2) or skills mismatches. Educational mismatches do not necessarily imply skills mismatches (Quintini, 2011; OECD, 2013a). The former ignores the possibility that workers with the same level of education may be heterogeneous in the level of skills acquired through experience, on-the-job training, or even stemming from differences in innate ability (Chevalier, 2003; Chevalier and Lindley, 2009). Moreover, skills acquired through education are likely to depreciate over time so that educational mismatches may be an imperfect proxy for jobrelated skills mismatches, especially among older workers. Therefore, a growing literature focuses on skills mismatches. A worker is considered under-skilled (or over-skilled) if she/he suffers a skill deficit (or surplus) in a specific field of knowledge, e.g. literacy or numeracy, needed to perform her job.

Using PIACC data the OECD has developed a novel approach to measure skills mismatches in literacy and numeracy. A survey asked workers whether they feel they "have the skills to cope with more demanding duties than those they are required to perform in their current job" and whether they feel they "need further training to cope well with their present duties". To compute the OECD measure of skills mismatches, workers are classified as well-matched in a domain if their proficiency score in that domain is between the minimum and maximum score observed among workers who answered "no" to both questions in the same occupation and country. Workers are over-skilled in a domain if their score is higher than the maximum score of self-reported well-matched workers, and they are under-skilled in a domain if their score is lower than the minimum score of self-reported well-matched workers. The OECD measure of skills mismatch is an improvement over existing indicators. However, this approach does not measure all forms of skills mismatch; rather, it focuses on mismatches in the proficiency domains assessed by PIAAC.

International experience suggests that the productivity-enhancing effect of advanced education is greater among the most productive and innovative firms that are part of the efficiency frontier or located close to it (Aghion et al., 2006, 2009). However, recent estimates for Belgium show that workers with a university/master's degree are not allocated differently to other workers. Many of them are in firms that are distant from the "efficiency frontier" suggesting that they could be more productive in frontier firms. Moving more workers with tertiary education to firms closer to the efficiency frontier would have a large impact on productivity - a 10 percentage point increase in the share of these workers in frontier firms could raise MFP growth by 2.5 percentage points (Box 5, Figure 13.A). The size of the effect declines the further the firm is from the technological frontier.

\section{Box 5. The productivity of university-educated workers as a function of the distance to the efficiency frontier}

The impact of university workers on firm productivity is estimated on the basis of Belgian firm-level data, covering the 2008-13 period in three steps.

- First, each firm's MFP level is estimated on the basis of the capital and labour parameters of a log-linearized Cobb-Douglas technology using OLS but also Levinsohn \& Petrin (LP) and Ackerberg, Caves \& Fraser (ACF) methods to account for endogeneity.

- Second, each firm's distance to the MFP frontier is estimated by computing the difference (in logs) between a firm's MFP and the $99^{\text {th }}$ percentile of its NAICS 2-digit industry-specific MFP distribution; each measure also being year-specific.

- Third, each firm MFP annual growth rate is regressed on i) the share of university-educated workers $S^{u n i v}$ it-1, ii) its distance to the efficiency frontier InDTFit-1 and iii) the interaction between these two variables, whose sign provides a direct test of the Aghion et al. assumption

$$
g_{i t}=I n M F P_{i t}-\operatorname{InMFP}_{i t-1}=\alpha+\beta \operatorname{InDTF_{it-1}}+\delta S^{\text {univ }}{ }_{i t-1}+\rho S_{i t-1}^{\text {univ }} * \ln D T F_{i t-1}+\tau F_{i t}
$$

$\rho>0$ can be interpreted as evidence that the closer firms are from their MFP frontier, the more the presence of university-educated workers matters for their MFP growth performance. 
Figure 13. There is room to better allocate university-educated workers
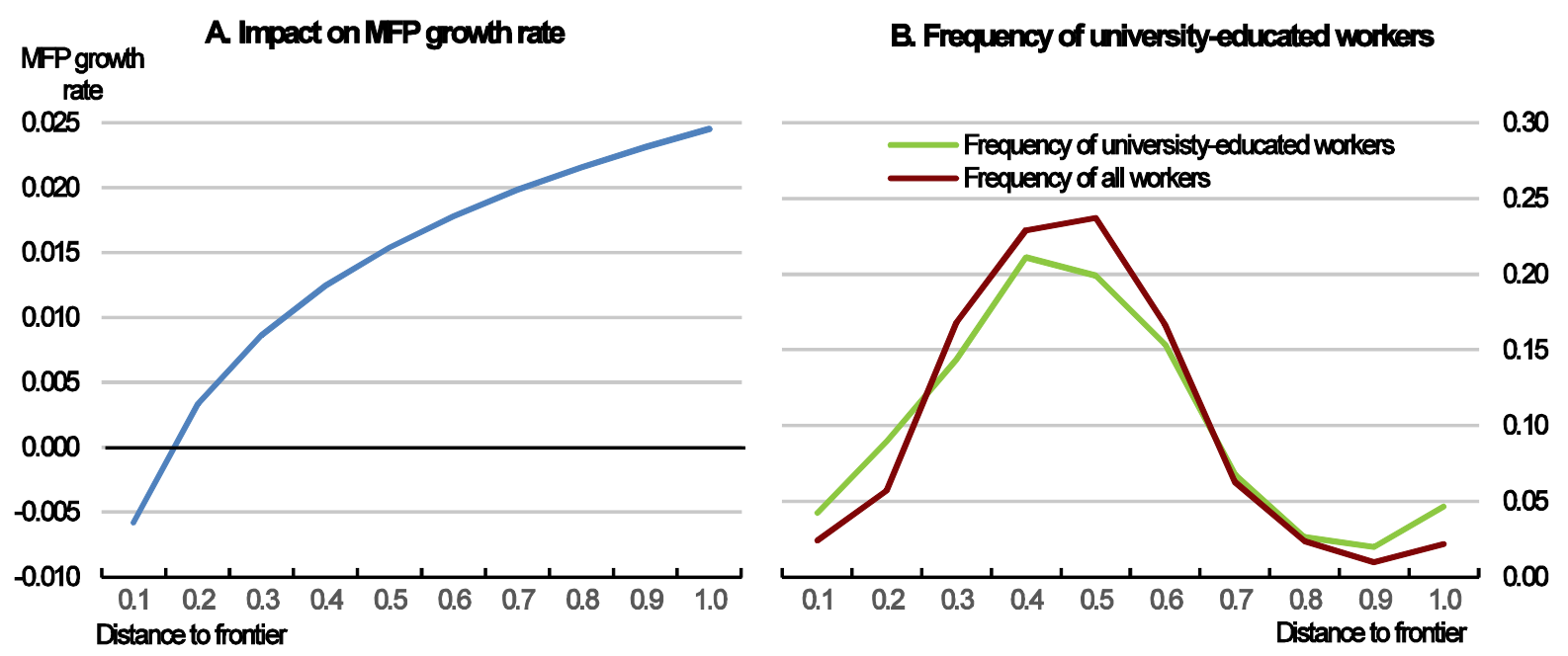

Note: In panel A, the left-hand vertical axis measures the impact on annual firm-level productivity growth of a $10 \%$-points rise of the share of workers with a university degree. The closer the firm to the frontier the larger the positive impact of university education on productivity growth and below a certain threshold that contribution is even negative. The right-hand axis (and the two frequency curves) measures the distribution of the workforce according to the distance to the efficiency frontier of the firm they work in. The distance to the efficiency frontier is computed as the difference (in logs) between a firm's MFP and the 99th percentile of its NAICS 2 digit industry MFP distribution (i.e. the frontier).

Source: Vandenberghe (2016).

\section{Establishing institutions to foster more efficient allocation of students and skills}

Residential mobility in Belgium is comparatively low, with about $10 \%$ of workers moving within a two-year period (Figure 14.A). This contributes to skills mismatches as residential mobility is positively correlated with the worker reallocation rate (Caldera Sánchez and Andrews, 2011). Aligning housing-related regulations to best practices, especially by reducing high transactions costs for house sales, could improve productivity gains (Figure 14.B). Reducing the severe road congestion problem by improving public transportation and adequate direct pricing of the use of roads would greatly facilitate the geographical mobility of the labour force and contribute to raise job-to-job mobility. 
Figure 14. Geographical mobility and worker reallocation is low

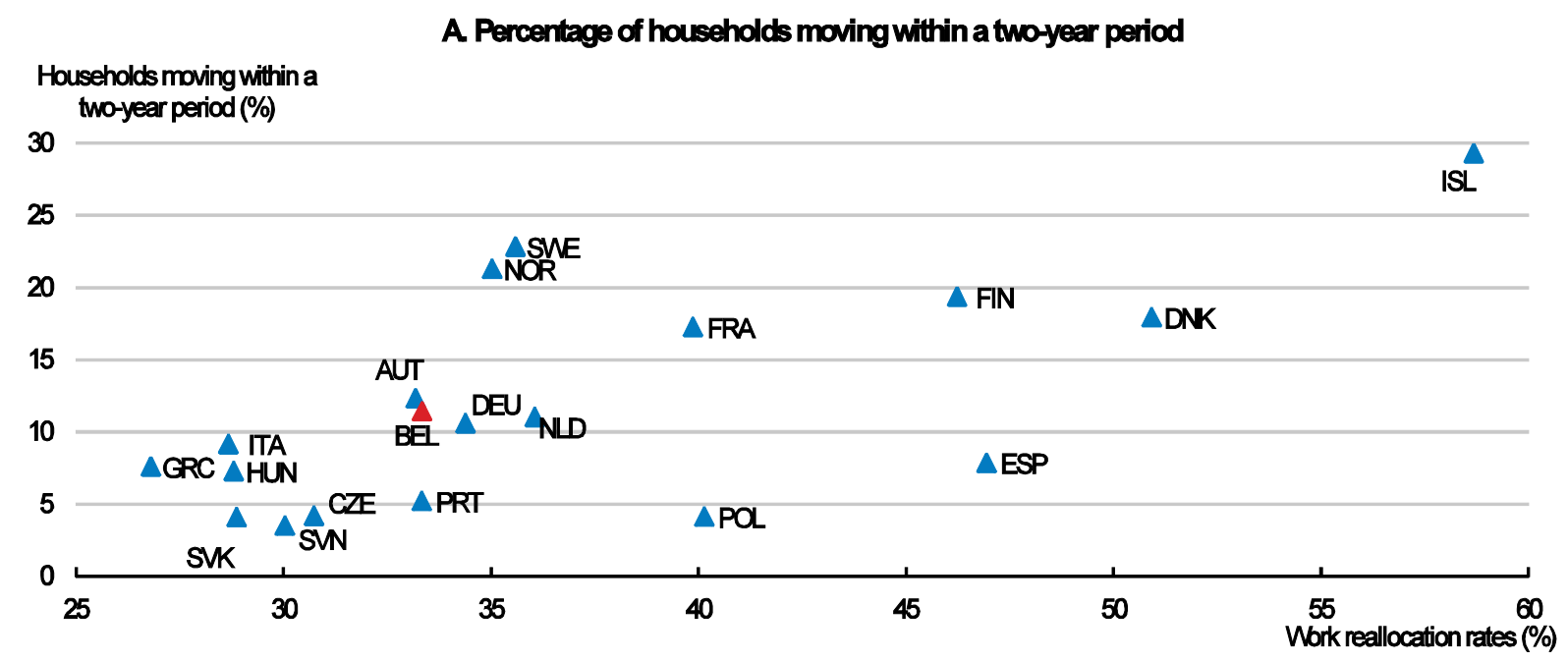

B. Decline in skill mismatch from recucing transaction costs on buying dwellings

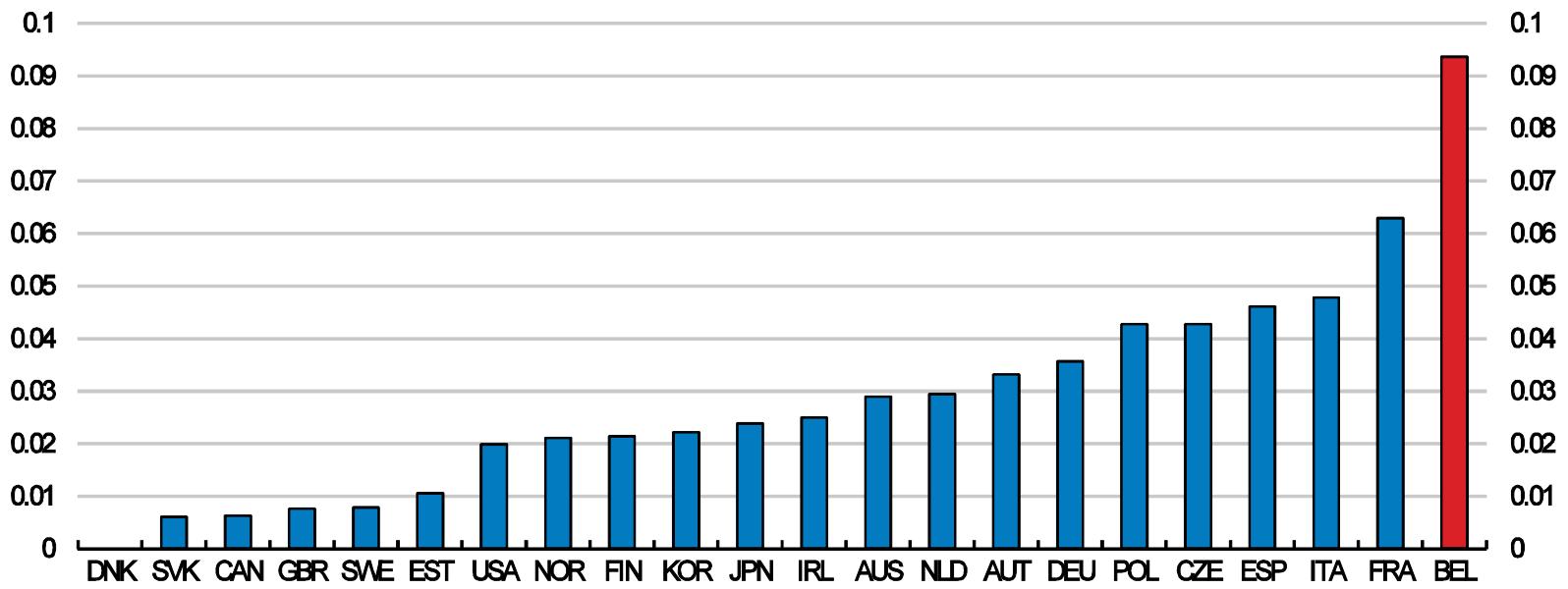

Note: In Panel A, worker reallocation rates are country averages of reallocation rates (hiring and firing rates) expressed as a percentage of total dependent employment. The data refer to 2000-07 or a shorter time period depending on data availability. Residential mobility data are from Andrews et al. (2011) based on 2007 EU-SILC Database, on HILDA for Australia, AHS for the United States and SHP for Switzerland.

In Panel B, the figure reports the impact on the probability of skills mismatch: if Belgium reformed transaction costs to best practice the probability of skills mismatch would fall by more than $9 \%$. Transaction costs include a number of fees such as transfer taxes (e.g. stamp duties), registration fees incurred when registering the property in the land registry, notarial or other legal fees and typical real estate agency fees and refer to 2009. Denmark has the lowest transaction costs.

Source: Caldera Sánchez and Andrews, 2011 and; Adalet and Andrews, 2015.

Business dynamism (i.e. the propensity of relatively less productive firms to die and be replaced by relatively more productive ones) is also comparatively low (see Chapter 1). This may lock resources in low-productivity firms. Empirical evidence shows that healthy market economies typically exhibit a high pace of churning of outputs and inputs (including workers) across businesses and that churning is productivity-enhancing as outputs and inputs move from less productive to more productive businesses (Bartelsman et al., 2009). Comparatively stringent product market regulation and high barriers to entry that protect low-productivity incumbents contribute to skills mismatches and dampen productivity growth by preventing new firms from entering and making better use of highly skilled workers (Figure 15). 
Figure 15. Easing product market regulation could reduce skills mismatches

Impact of product market regulation reform

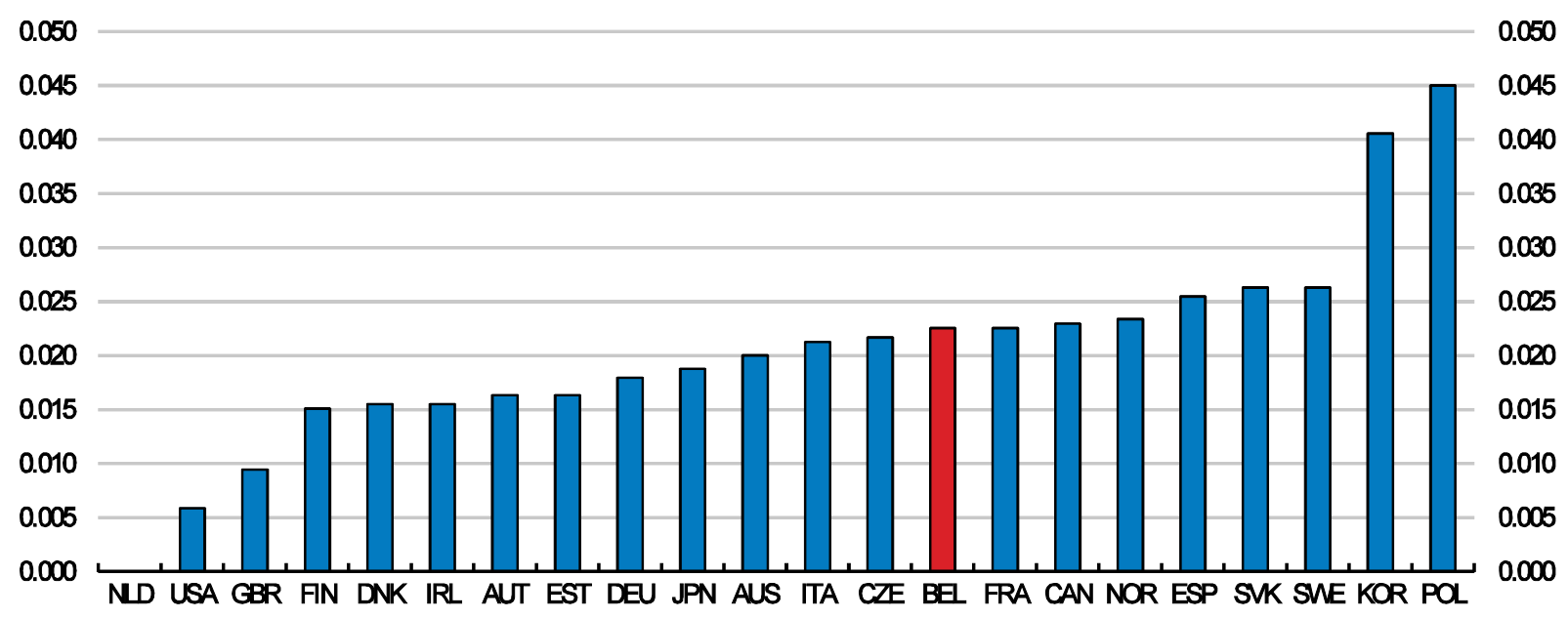

Note: The figure reports the impact on the probability of skills mismatch: if Belgium reformed product market regulation to best practice the probability of skills mismatch would fall by almost $2.5 \%$. Product Market Regulation is the aggregate indicator for 2008. The Netherlands has the least stringent product market regulation.

Source: Adalet and Andrews, 2015.

Belgium has relatively strict employment protection legislation (EPL). Strict EPL may contribute to skills mismatches by preventing firms from adapting their workforce to technological (or business cycle) changes, or by reducing professional mobility between jobs (Eurostat, 2017). Fixed-term and temporary contracts help, but developing such atypical contracts comes with the risk of reducing, from an already low level, firms' investment in training. One factor undermining job mobility might be the prevalence of seniority wages (Figure 4) and perks that are, de facto, indexed on seniority (e.g. extra legal pensions and stock options).

Ensuring that the allocation of students among the different fields of study is broadly in line with labour market needs is a first step towards a more efficient allocation of resources. Within most fields of study a bachelor's or master's degree delivers a positive wage premium, with a long/master's degrees on average paying more than short/bachelor's degrees. However, wage premia vary greatly between fields of study (Annex 2). This suggests there room for some reallocation of students across fields of study within tertiary education. In a system where individuals have ample freedom of choice, with regard to both institutions and fields of study, achieving reallocation is challenging. A first step would simply consist of largely disseminating data on wage premia by field of study instead of just by level of study. This might entice more prospective students to choose fields of study more relevant to the labour market. 


\section{The promises and challenges of digitalisation}

Digitalisation holds the promise of large labour productivity gains. There is no consensus on the scope for future digitalisation (big data, internet-of-things...). However, if growth in computation and artificial intelligence crosses a certain threshold, productivity growth could accelerate sharply as improvements cascade through the economy at an ever-accelerating pace. Some consider the current low growth environment to be transitory and expect a "second machine age" to lead to a third industrial revolution (Brynjolfsson and McAfee, 2014).

Digitalisation-induced productivity gains are unlikely to be distributed evenly across the economy (CSE, 2016). Despite a large number of baby boomers retiring, some sectors where digitalisation accelerates will see large employment losses and a high degree of job transformation (Figure 16.A). Final demand for goods and services will re-orient; and other jobs will most likely be created elsewhere in the economy. Coping with these reallocations may require a lot of effort on the side of labour. Workers will need to move between tasks, jobs, firms, industries and perhaps also regions of residence. It is crucial to continue to strengthen the labour market institutions to help facilitate these transitions for workers. A lot has already been done in Belgium to activate welfare protection, for example individualised guidance or coaching, access to training, and a near-universal right to outplacement paid by the employer in case of dismissal. The agenda for the future should be focused on optimising and selectively amplifying existing policies. For that, much more evaluation of the actual use and the effectiveness of existing schemes is needed.

Digitalisation is also disrupting the nature of employment relationships, via the rise of internet jobs platforms and its corollary: on-demand jobs. There is no systematic data for Belgium, but evidence from the US suggests that these jobs could rapidly represent a non-negligible part of the total workforces. Krueger and Katz (2016) estimate that the percentage of US workers engaged as temporary help agency workers, on-call workers, contract workers, and independent contractors or freelancers rose from $11 \%$ in February 2005 to $16 \%$ in late 2015.

On-demand jobs have advantages, including more time flexibility and diversity for individuals and access to a larger pool of skills, lower costs of hiring, and lower administrative burdens for firms. They probably also contribute to higher labour productivity via an overall reduction of slack, a better adjustment of employment to fluctuations in final demand, and better use of the existing capital stock.

To level the playing field with existing forms of business the fiscal and social security status applicable to these on-demand workers needs to be clarified (Box 6). Many on-demand workers operate in a triangular relationship with an intermediary (e.g. Uber) using a proprietary application to identify customers for their services. One option would be to require the intermediaries to provide some welfare benefits and protection to these on-demand workers and to require them to enforce tax and social security contribution withholding services, as traditional employers do on behalf of salaried employees.

Important steps were recently taken to adapt tax legislation to the challenges of the sharing economy. In July 2016, Belgium introduced income tax legislation to improve the treatment of income obtained through the sharing economy. The law grants of an advantageous (but limited) tax regime for individual service providers who operate through a digital platform and requires tax withholding at source by the digital platform. In particular, the effective tax rate on income from the sharing economy that does not exceed EUR 5000 per year is fixed at $10 \%$ and collected based on electronic payment records of the digital platform. However, the scope of the new taxation framework remains limited to services that are provided between non-professional individuals, and excludes goods (e.g. takeaways) as well as the letting of real property (e.g. AirBnB) or movables (e.g. car-sharing). With such important parts of the sharing economy excluded, there is a risk that income from platform activities is not fully reported and distortions 
Figure 16. Building skills for the future

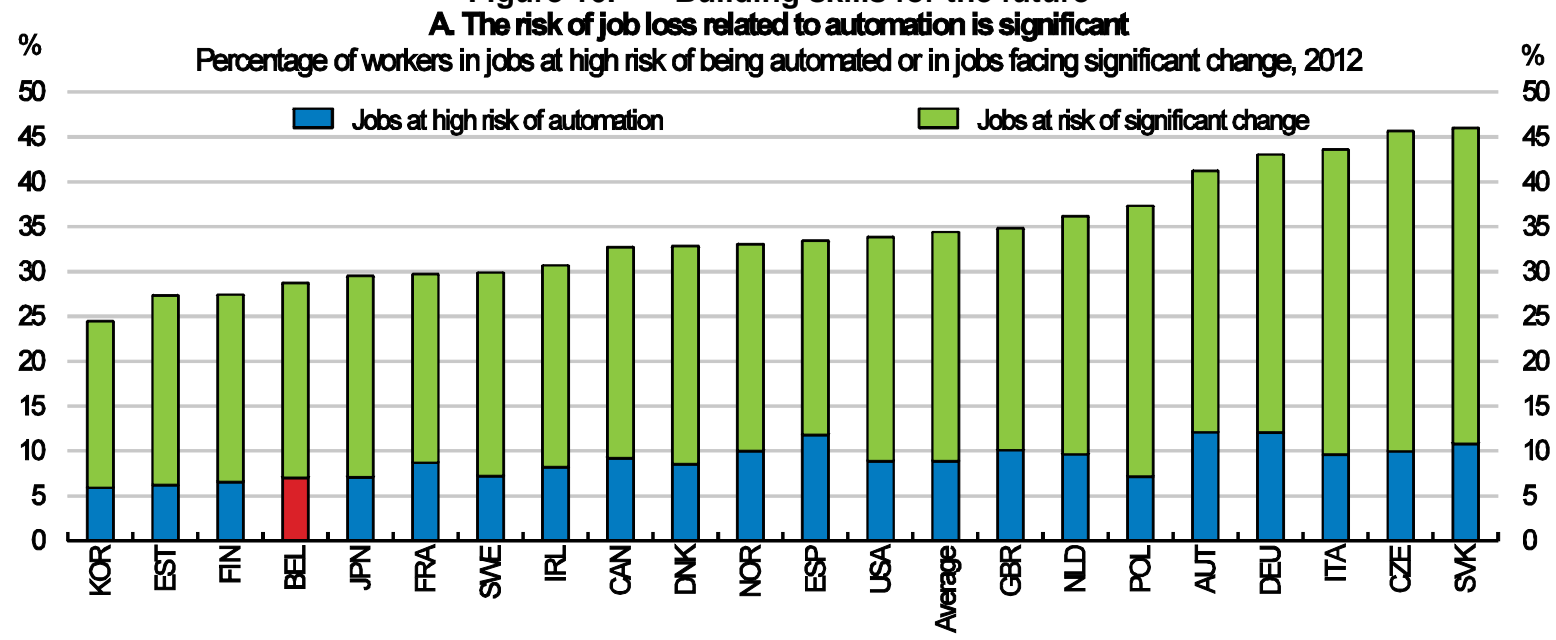

B. ICT skills shortage

Share of firms that offered jobs for ICT specialist that were difficult to fill, $\mathbf{2 0 1 5}$
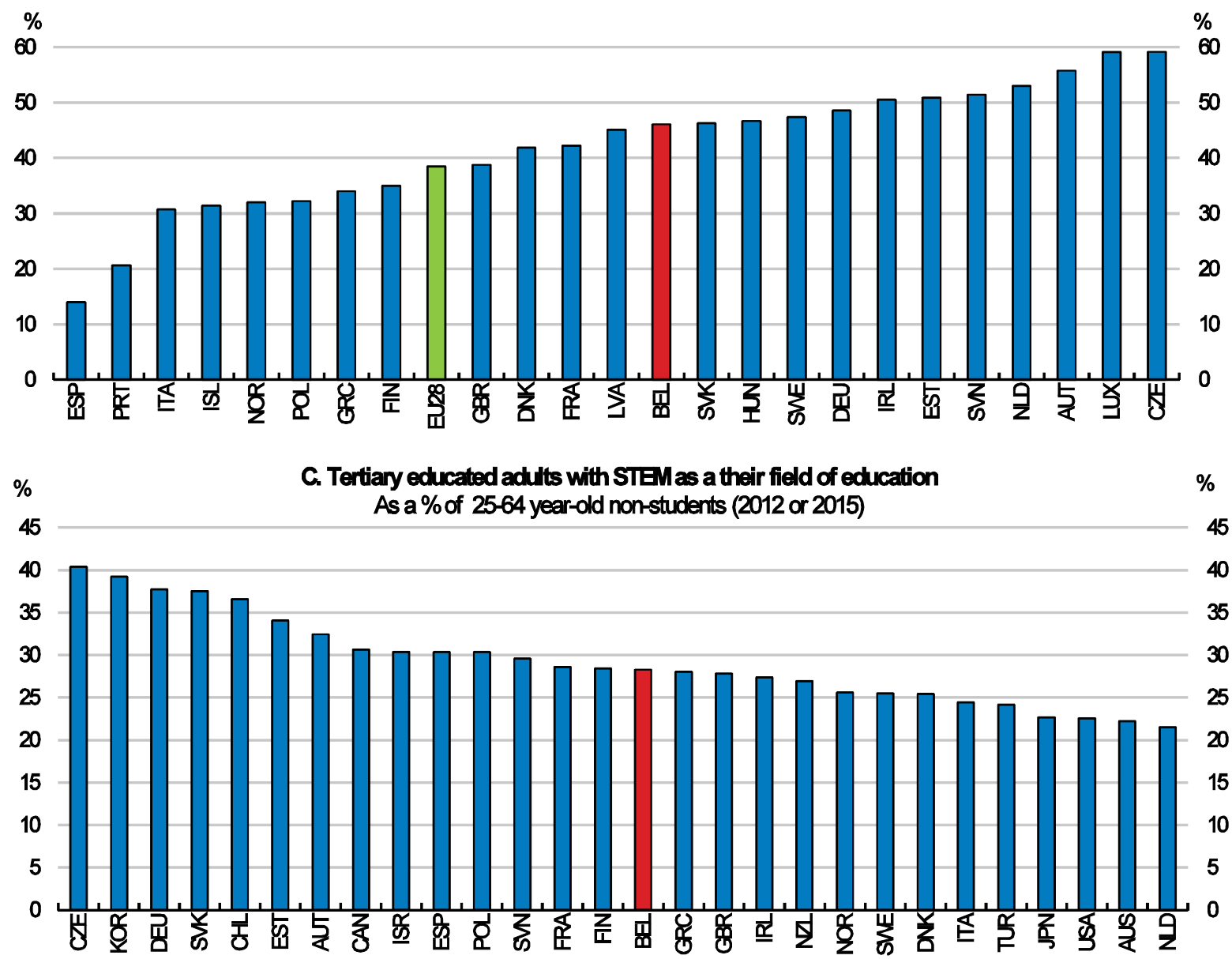

Note: In panel A, jobs are at high risk of automation if the likelihood of their job being automated is at least $70 \%$. Jobs at risk of significant change are those with the likelihood of their job being automated estimated at between 50 and $70 \%$. Data for Belgium correspond to Flanders and data for the United Kingdom to England and Northern Ireland.

In panel B, STEM refers to science, technology, engineering and mathematics subjects, data for Germany refer to 2014. For Iceland, data refer to 2012 and 2014.

In panel C, data for Chile, Greece, Israel, New Zealand, Singapore, Slovenia and Turkey refer to 2015. For all other countries, 2012 is the reference year. For Belgium, data refer to Flanders. For United Kingdom, data refer to England.

Source: Arntz and Zierahn (2016); Eurostat, Information Society database and; OECD Survey of Adult Skills (PIAAC) (2013, 2016). 
vis-à-vis traditional service providers persevere. In this context, the authorities should aim to broaden the coverage of the legislation to other activities within the sharing economy.

\section{Box 6. E-platforms, "alternative" jobs and the need for a relevant legal framework}

Digitalisation prompts major transformations in how work is organised; blurring the traditional distinction between "employee" and "self-employed". With high-speed internet, audio and video technology, etc. workers have the flexibility to work at any time and from anywhere. E-platforms are an important driver of this evolution, and could boost labour productivity. Employers can hire specialists on demand and keep their workforce flexible in response to demand fluctuations.

But there are also concerns about the protection of on-demand workers as well as their tax obligations. In a recent policy paper Harris and Krueger (2015) explain that "alternative" workers do not fit easily into the existing legal definitions of "employee" vs "self-employed". The distinction is important because employees qualify for a range of legally mandated welfare benefits that are not available to self-employed people, such as unemployment or occupational accident insurance. Instead they propose a new category of "independent workers" for those who occupy the grey area between traditional employees and self-employment. Most operate in a triangular relationship with a business (i.e., an intermediary like Uber or AirBnB) and customers. Typically, they use a communication channel, such as an app, created by an intermediary to identify customers for their services. Harris and Krueger recommend requiring (or allowing) intermediaries to provide some welfare benefits and protections to these "independent workers" (but not all, e.g. no fully-fledged unemployment insurance), but also require intermediaries to enforce tax and social security contribution withholding services, akin to what employers traditionally do on behalf of salaried employees.

Digitalisation creates an upskilling challenge. Although some recent technological developments (e.g. voice recognition) may lead to "deskilling" of some jobs and occupations, the bulk of existing evidence suggests higher skill requirements for those who work in ICT-rich environments, and certainly for those whose task consists of developing new goods and services (Brynjolfsson and McAfee, 2014). The labour demand for ICT specialists and people with coding skills seems to rise unabatedly, leading to more and more unfilled vacancies (Figure 16.B). For instance, in 2014 more than half of firms located in Belgium looking for an ICT specialist reported unfilled vacancies over relatively long periods (Eurostat, 2014).

Digitalisation is already changing the type of skills employers demand. Increasingly desirable skills range from basic digital literacy (e.g. browsing, sending emails) to advanced technical skills (e.g. big data analytics, app development). Moreover, it is the combination of foundation skills (literacy and numeracy) and skills directly related to technologies (e.g. coding) that make individuals employable (OECD, 2016a). This combination is especially important for medium-skilled white-collar workers, whose jobs will increasingly disappear due to technological change (Arntz et al, 2016). In the Belgian context, this will require a sharp rise in adult education and training, as discussed above. In Wallonia Centres de Compétences have been set up in strategic areas and sectors with a solid technology base and aim to support innovation and growth through the development of relevant skills. The model is based on a partnership approach and the centres intervene both upstream (through monitoring, information, awareness, etc.) and downstream (though validation of skills, improved integration courses, etc.) A similar approach exists in Flanders with the kennisinstellingen. The strategic research centres Imec (semiconductors, etc.) and iMinds (software) merged at the end of 2016, and the budget increased towards a total of EUR 110 million a year. In addition, a transition path for Industry 4.0 was approved by the Flemish Government in March 2017.

The dissemination of basic digital literacy should be the most effective way to ensure the labour force is appropriately skilled. It will come as a by-product of the growing availability of digital products and services, the reduction of the price of broadband internet and mobile communications, or from the ability of citizens to conduct all communication with the government digitally (a 2020 objective, part of the "Digital Belgium" agenda). A plus would be to systematically offer basic ICT training to groups at risk of the so-called digital divide. 
The proliferation of advanced ICT skills - i.e. those related to application development and web development, scriptwriting and virtualisation, or underpinning the development of the cloud - will probably continue to depend on attracting youth to study science, technology, engineering and mathematics (STEM) subjects. In 2013 only 17\% of students in tertiary education enrolled in STEM subjects (Figure 16.C). Although, STEM enrolment in the Flemish community increased over the past few years and more students are enrolled in courses that partly integrate STEM subjects in the curriculum. Moreover, women are largely underrepresented (OECD, 2016b). The Flemish government has launched a STEM Action Plan aimed at increasing the number of students opting for STEM disciplines, particularly within the fields of technology and ICT. However, more needs to be done to properly inform prospective students that the field of study matters in terms of job prospects and future earnings.

The dissemination of intermediate coding skills could be achieved via increased participation in adult education and training (AET). For younger people it may happen outside fully fledged STEM programmes, via the generalisation of ICT minors (i.e. as a student's declared secondary academic discipline) accessible to any tertiary education student; and at a fraction of the cost of traditional STEM programmes.

\section{Policy recommendations to raise skills for higher productivity growth and more inclusiveness}

Key recommendations

- Ensure firms comply with the new Federal legislation to provide workers with at least five working days of education and training per year. Develop flexitime and abolish remaining early retirement schemes.

- Where appropriate, expand controlled school-choice schemes in the Communities to reduce the concentration of pupils with a non-EU immigrant background. Improve teacher training and incentives to attract teachers to schools with a high concentration of disadvantaged pupils.

- Where appropriate, consider increasing or adjusting tuition fees, while maintaining the grant and waiver system for disadvantaged students along with income-contingent loans. Better publicise labour market shortages and wage premia to motivate students to choose fields of study more relevant to the labour market.

\section{Further recommendations}

- Foster efforts to reduce the steepness of seniority profiles through the well-established bargaining wage process.

- Improve professional mobility by investing in public transport, reducing transaction costs in the housing market and applying direct pricing on the use of roads.

- Increase spending per student in elementary education to at least the level of that of secondary education.

- Support dissemination of intermediate ICT skills (including coding) through both adult education and training and by generalising access to ICT minors for all tertiary education students.

- Increase the coverage of existing legislation on the sharing economy to include a broader range of activities. 
ECO/WKP(2017)84

\section{REFERENCES}

Adalet McGowan, M. and D. Andrews (2015), "Labour Market Mismatch and Labour Productivity: Evidence from PIAAC Data”, OECD Economics Department Working Papers, No. 1209, OECD Publishing, Paris, http://dx.doi.org/10.1787/5js1pzx1r2kb-en.

AES (2011), European Commission Adult Education Survey, http://ec.europa.eu/eurostat/web/microdata/adult- education-survey.

Aghion, P., C. Meghir and J. Vandenbussche (2006), "Distance to Frontier, Growth, and the Composition of Human Capital”, Journal of Economic Growth, 11(2), pp. 97-127.

Aghion, P., L. Boustan, C. Hoxby and J. Vandenbussche (2009), "The Causal Impact of Education on Economic Growth: Evidence from United States”, in Romer, D. \& Wolfers, J. (Eds.), Brookings Papers on Economic Activity: Conference Draft, Brookings, Washington, DC.

Andrews, D. and F. Cingano (2014), "Public policy and resource allocation: Evidence from firms in OECD countries”, Economic Policy, CEPR.

Appannah, A. and S. Biggs (2015), “Age-Friendly Organisations: The Role of Organisational Culture and the Participation of Older Workers”, Journal of Social Work Practice, 29(1), pp. 37-41.

Arntz, M., T. Gregory and U. Zierahn (2016), "The Risk of Automation for Jobs in OECD Countries: A Comparative Analysis”, OECD Social, Employment and Migration Working Papers, No. 189, OECD Publishing, Paris, http://dx.doi.org/10.1787/5jlz9h56dvq7-en.

Barro, R. and J.W. Lee (2016), Barro-Lee Educational Attainment Data, www.barrolee.com/main.htm.

Bartelsman, E., J. Haltiwanger and S. Scarpetta (2009), "Measuring and Analyzing Cross-country Differences in Firm Dynamics”, NBER Chapters, in: Producer Dynamics: New Evidence from.

Becker, G. (1964), Human Capital, National Bureau of Economic Research, New York.

Blanchet, D., E. Caroli, C. Prost and M. Roger (2016), "Health Capacity to Work at Older Ages in France”, NBER Chapters, in: Social Security Programs and Retirement Around the World: The Capacity to Work at Older Ages, National Bureau of Economic Research, Inc.

Brynjolfsson, E. and A. McAfee (2014). The Second Machine Age: Work Progress, and Prosperity in a Time of Brilliant Technologies. New York: W.W. Norton \& Company.

Caldera Sánchez, A. and D. Andrews (2011), "Residential Mobility and Public Policy in OECD Countries”, OECD Journal: Economic Studies, Vol. 2011/1, http://dx.doi.org/10.1787/eco_studies-2011$5 \mathrm{~kg} 0 \mathrm{vswqt} 240$.

Chevalier, A. (2003), “Measuring over-education”, Economica, 70: 509-531. 


\section{ECO/WKP(2017)84}

Chevalier, A. and Lindley, J. (2009), “Overeducation and the skills of UK graduates”, Journal of Royal Statistical Society, 172: 307-337.

CSE (2016), Économie numérique et marché du travail, Conseil supérieur de l'emploi.

Department for Education (2016), Participation Rates in Higher Education, Department of Education, www.gov.uk/government/uploads/system/uploads/attachment_data/file/552886/HEIPR_PUBLICATION_ 2014-15.pdf.

EC (2015), National Student Fee and Support Systems in European Higher Education 2015/16, European Commission.

EC (2016), Education and Training Monitor 2016, Belgium, European Commission.

Eurostat (2014), http://ec.europa.eu/eurostat/statisticsexplained/index.php/File:V1_Enterprises_that_recruited_ICT_specialists,_with_and_without_diffi culties_in_filling_vacancies,_2014_(\%25_enterprises).png\#file.

Eurostat (2017), http://ec.europa.eu/eurostat/web/products-datasets/-/hrst_fl_mobsect2. Freeman, R. (1976), The Overeducated American, American Press, NY.

Gérard, M. and V. Vandenberghe (2007), "Mobilité étudiante en Europe : une idée qui mérite mieux que des quotas”, Regards Economiques, No. 54, IRES, Université catholique de Louvain.

Giuliano, R., B. Mahy, F. Rycx and G. Vermeylen (2017), "Does corporate social responsibility make overeducated workers more productive?”, Applied Economics, http://dx.doi.org/10.1080/00036846.2016.1203061.

Harris, S. and A. Krueger (2015), “A Proposal for Modernizing Labor Laws for Twenty-First-Century Work: The “Independent Worker”, The Hamilton Project, Discussion Paper No. 2015-10.

Heckman, J. (2008), “Schools, Skills, and Synapses”, Economic Inquiry, Vol. 46, No. 3, July, pp. 281-324.

Kampelmann, S. and F. Rycx (2012), “The impact of educational mismatch on firm productivity: Evidence from linked panel data”, Economics of Education Review, 31(6): 918-931.

Kantarci, T. and A. Van Soest (2008), “Gradual Retirement: Preferences and Limitations”, Paper for the Netspar Panel debate.

Karakaya, G., R. Plasman and F. Rycx (2007), “Overeducation on the Belgian labour market: Evaluation and analysis of the explanatory factors through two types of approaches", Compare: A Journal of Comparative and International Education, 37(4): 513-532, 2007.

Kirsten, D. and J. Heywood (2007), “The Determinants of Hiring Older Workers: UK Evidence”, Labour Economics 14(1), pp. 35-51.

Krueger, A. and L. Katz (2016), “The Rise and Nature of Alternative Work Arrangements in the United States 1995-2015”, NBER Working Paper No. 22667, NBER.

Lallemand, T. and F. Rycx (2009), “Are Older Workers Harmful for Firm Productivity ?”, De Economist (Netherlands Economic Review), Vol. 157, No. 3, pp. 273-292. 
Lazear, E. (1979), “Why is there mandatory retirement?”, Journal of Political Economy, Vol. 87, No. 6, pp. 1261-1284.

Lebedinski, L. and V. Vandenberghe (2014), “Assessing education’s contribution to productivity using firm-level evidence”, International Journal of Manpower, 35(8): 1116-1139.

Leuven, E. and H. Oosterbeek (2011), “Overeducation and mismatch in the labor market”, in:

E. Hanushek, S. Machin and L. Woessmann (eds.), Handbook of the Economics of Education, Volume 4, Elsevier, Amsterdam.

Loch, C., J.S. Sting, N. Bauer and H. Mauermann (2010, March), "The Globe: How BMW Is Defusing the Demographic Time Bomb”, Harvard Business Review, retrieved from https://hbr.org/2010/03/theglobe- how-bmw-is-defusing-the-demographic-time-bomb.

Nusche, D. et al. (2015), “OECD Reviews of School Resources: Flemish Community of Belgium 2015”,

OECD Reviews of School Resources, OECD Publishing, Paris.

OECD (2013a), OECD Skills Outlook 2013: First Results from the Survey of Adult Skills, OECD Publishing, Paris, http://dx.doi.org/10.1787/9789264204256-en.

OECD (2013b), Survey of Adult Skills (PIACC), http://www.oecd.org/skills/piaac/publicdataandanalysis/\#d.en.408927.

OECD (2013c), TALIS database, http://stats.oecd.org/index.aspx?datasetcode=talis_2013\%20.

OECD (2015), OECD Economic Surveys: Belgium 2015, OECD Publishing, Paris, http://dx.doi.org/10.1787/ eco_surveys-bel-2015-en.

OECD (2016a), “Skills for a Digital World: 2016 Ministerial Meeting on the Digital Economy Background Report”, OECD Digital Economy Papers, No. 250, OECD Publishing, Paris, http://dx.doi.org/10.1787/ 5jlwz83z3wnw-en.

OECD (2016b), Education at a Glance 2016, Country note Belgium, OECD Publishing, Paris.

OECD (2016c), Education at a Glance 2016: OECD Indicators, OECD Publishing, Paris, http://dx.doi.org/ 10.1787/eag-2016-en.

OECD (2017), Labour force statistics Database, www.oecd.org/std/labour-stats/.

Quintini, G. (2011), “Over-Qualified or Under-Skilled: A Review of Existing Literature”, OECD Social, Employment and Migration Working Papers, No. 121, OECD Publishing, Paris, http://dx.doi.org/10.1787/ 5kg58j9d7b6d-en.

Rycx, F., Y. Saks and I. Tojerow (2015), "Does education raise productivity and wages equally? The moderating roles of age, gender and industry”, IZA Discussion Paper, No. 9043, Bonn.

UNESCO (2016), http://data.uis.unesco.org/.

Vacature (2008), Salarisenquête 2008, Vacature. 


\section{ECO/WKP(2017)84}

Vacature (2010), Salarisenquête 2010, Vacature.

Vacature (2012), Salarisenquête 2012, Vacature.

Vandenberghe, V. (2011a), "Boosting the employment rate of older men and women. An empirical assessment using Belgian firm-level data on productivity and labour costs”, De Economist, 159(2), pp. 159-191.

Vandenberghe, V. (2011b) "Firm-level Evidence on Gender Wage Discrimination in the Belgian Private Economy”, Labour: Review of Labour Economics and Industrial Relations, 25(3), pp. 330-349.

Vandenberghe, V. (2016), "Human capital. Assessing the Distance-to-Frontier Assumption Using FirmLevel Evidence”, Mimeo, IRES, UCL, Belgium.

Vandenberghe, V. (2017), “The Productivity Challenge. What can be expected from better-quality labour and capital inputs?”, Applied Economics.

Vandenberghe, V., M. Rigo and F. Waltenberg (2013), “Ageing and Employability. Evidence from Belgian Firm-Level Data”, Journal of Productivity Analysis, 40(1), pp. 111-136.

van Ours, J.C. and L. Stoeldraijer (2010), “Age, Wage and Productivity”, IZA Discussion Papers 4765, Institute for the Study of Labor (IZA). 
ANNEX A.1

\section{Firm-level analysis of workforce composition's impact on productivity}

\section{The Hellerstein-Neumark Methodology}

The methodology to estimate productivity (and/or wage) profiles according to a given characteristic of the workforce (e.g.; age, gender or education attainment), is a simplified version of the Hellerstein-Neumark approach, recently applied on Belgium data by Lallemand \& Ryckx, 2009; Vandenberghe 2011a, 2013; Vandenberghe et al., 2013.

Following most authors in this area, we consider a Cobb-Douglas technology (Hellerstein et al., 1999; van Ours \& Stoeldraijer, 2011; Vandenberghe, 2011a,b):

$$
\ln \mathrm{Yit}=\ln \mathrm{A}+\alpha \ln \mathrm{QLit}+\beta \ln \mathrm{Kit} \quad[1]
$$

where: Yit /Lit is the average value added per worker (average productivity hereafter) in firm i at time t, QLit is an aggregation of different types of workers, and Kit is the stock of capital.

The variable that reflects the heterogeneity of the workforce is the quality of labour index QLit. Let Lijt be the number of workers of type j (e.g. young /old; men/women; low/high educated) in firm i at time t, and $\mu \mathrm{ij}$ be their contribution to output. We assume that workers of various types are substitutable with different marginal products. As each type of worker $\mathrm{j}$ is assumed to be an input in quality of labour aggregate, the latter can be specified as:

$$
\mathrm{QLit}=\sum \mathrm{j} \mu \mathrm{ij} \mathrm{Lijt}=\mu \mathrm{i} 0 \mathrm{Lit}+\sum \mathrm{j}>0(\mu \mathrm{ij}-\mu \mathrm{i} 0) \text { Lijt } \quad[2]
$$

where: Lit $\equiv \sum \mathrm{j}$ Lijt is the total number of workers in the firm, $\mu \mathrm{i} 0$ the marginal productivity of the reference category of workers (e.g. prime-age men) and $\mu$ ij that of the other types of workers.

If we further assume that a worker has the same marginal product across firms, we can drop subscript $\mathrm{i}$ from the marginal productivity coefficients. After taking logarithms and doing some rearrangements equation (2) becomes:

$$
\ln \mathrm{QLit}=\ln \mu 0+\ln \mathrm{Lit}+\ln \left(1+\sum \mathrm{j}>0(\lambda \mathrm{j}-1) \mathrm{Sijt}\right)
$$

where $\lambda \mathrm{j} \equiv \mu \mathrm{j} / \mu 0$ is the relative marginal productivity of type $\mathrm{j}$ worker and $\mathrm{Sijt} \equiv \mathrm{Lijt} / \mathrm{Lit}$ the share of type $\mathrm{j}$ workers over the total number of workers in firm $\mathrm{i}$. 
Since $\ln (1+x) \approx x$, we can linearize [3] by:

$$
\ln \mathrm{QLit}=\ln \mu 0+\ln \mathrm{Lit}+\sum \mathrm{j}>0(\lambda \mathrm{j}-1) \mathrm{Sjt} \quad[4]
$$

And the production function becomes:

$$
\ln Y i t=\ln A+\alpha\left[\ln \mu 0+\ln \operatorname{Lit}+\sum j>0(\lambda j-1) \operatorname{Sijt}\right]+\beta \ln K i t[5]
$$

Or, equivalently, if $\mathrm{j}=0,1, \ldots . \mathrm{N}$ with $\mathrm{j}=0$ being the reference group (e.g. prime-age male workers)

$$
\text { yit }=\mathrm{B}+\eta 1 \mathrm{Si} 1 \mathrm{t}+\ldots \eta \mathrm{N} \mathrm{SiNt}+\alpha \text { lit }+\beta \text { kit }[6]
$$

where:

$$
\begin{gathered}
B=\ln A+\alpha \ln \mu 0 ; \\
\eta j=\alpha(\lambda j-1), \lambda j=\mu j / \mu 0 \quad j=1 . . N \\
y i t=\ln Y i t ; l i t=\ln L i t ; k i t=\operatorname{lnKit}
\end{gathered}
$$

Finally, if we focus on the (log of) labour productivity and assume constant returns to scale $(\alpha+\beta=1)$ expression [6] becomes

$$
\begin{gathered}
\text { yit }- \text { lit= TFPit }+ß(\text { kit }- \text { lit })[7] \\
\text { where } \\
\text { TFPit }=\text { B }+\eta 1 \text { Si1t }+\ldots \eta N \text { SiNt } \\
\text { kit -lit= capital intensity }
\end{gathered}
$$

Note first that [6], [7] being loglinear in S, have coefficients can be directly interpreted as the percentage change in the firm's average labour productivity of a 1 unit (here 100 percentage points) change of the considered type of workers' share among the employees of the firm. Note also that, strictly speaking, to obtain a type $\mathrm{j}$ worker's relative marginal productivity, (i.e. $\lambda \mathrm{j}$ ), coefficients $\eta \mathrm{j}$ should be divided by $\alpha$, and 1 needs to be added to the result.

The key point is that the njSijt terms appear as direct components of TFP, while the last term is capital intensity. And in dynamics terms, conditional on the different types of labour being not equally productive (i.e. estimated $\eta \mathrm{j}$ being different that zero (one)), we have that a change of the overall mix of the labour force should directly impact TFP growth 
ECO/WKP(2017)84

\section{Results}

Firm-level estimation of marginal labour productivity: age, gender and educational attainment 3 age groups: $<35,35-49[$ ref], $50+$

\begin{tabular}{|c|c|c|}
\hline & Model 1 & Model 2 \\
\hline \multirow[t]{2}{*}{$\operatorname{lnK}_{\text {it }}(ß)$} & $0.1987^{\star \star \star}$ & $0.1896 * \star \star$ \\
\hline & $(0.0025)$ & $(0.0026)$ \\
\hline \multirow[t]{2}{*}{$\operatorname{lnL} L_{i t}(\alpha)$} & $0.8104^{\star \star *}$ & $0.8217^{\star * \star}$ \\
\hline & $(0.0036)$ & $(0.0038)$ \\
\hline \multirow{2}{*}{ Share $<35\left(\eta_{<35}\right)$} & $-0.2538^{* * *}$ & $-0.1643^{* * *}$ \\
\hline & $(0.0291)$ & $(0.0282)$ \\
\hline \multirow[t]{2}{*}{ Share $50+(n 50+)$} & $-0.1184^{\star \star \star}$ & -0.1449 *** \\
\hline & $(0.0332)$ & $(0.0325)$ \\
\hline \multirow[t]{2}{*}{ Share female $\left(n_{F}\right)$} & $-0.0370^{*}$ & $-0.0590^{\star *}$ \\
\hline & $(0.0154)$ & $(0.0185)$ \\
\hline \multirow[t]{2}{*}{ Share secondary $\left(\eta_{\mathrm{sec}}\right)$} & $0.0413^{\star \star \star}$ & $0.0372^{\star \star}$ \\
\hline & $(0.0125)$ & $(0.0121)$ \\
\hline \multirow[t]{2}{*}{ Share bachelor $\left(\eta_{\mathrm{Bac}}\right)$} & $0.4720^{\star \star \star}$ & $0.4133^{\star \star \star *}$ \\
\hline & $(0.0189)$ & $(0.0191)$ \\
\hline \multirow[t]{2}{*}{ Share master ( $\left.\eta_{\text {Mas }} \mathrm{t}\right)$} & $0.7566^{\star \star \star}$ & $0.7572^{\star \star \star}$ \\
\hline & $(0.0272)$ & $(0.0283)$ \\
\hline \multirow[t]{2}{*}{ _cons (B) } & $3.3578^{\star \star *}$ & $4.3167^{\star \star \star *}$ \\
\hline & $(0.0252)$ & $(0.4096)$ \\
\hline $\mathrm{R}^{2}$ & .87 & .88 \\
\hline Nobs & 18950 & 18950 \\
\hline \multicolumn{3}{|c|}{$\begin{array}{l}\text { Implies marginal labour productivities } \\
\qquad \lambda(1=\text { ref category })\end{array}$} \\
\hline Old $\left(\lambda_{50+}\right)$ & 0.854 & 0.824 \\
\hline Female $\left(\lambda_{F}\right)$ & 0.954 & 0.928 \\
\hline Secondary $\left(\lambda_{50+}\right)\left(\eta_{\mathrm{Sec}}\right)$ & 1.051 & 1.045 \\
\hline Bachelor $\left(\lambda_{50+}\right)\left(\eta_{\mathrm{Bac}}\right)$ & 1.582 & 1.503 \\
\hline Master $\left(\lambda_{50+}\right)$ ( $\left.\eta_{\text {Mast }}\right)$ & 1.934 & 1.922 \\
\hline Controls & Year & $\begin{array}{l}\text { Year, Nace3-digit, date of } \\
\text { incorporation, provinces }\end{array}$ \\
\hline
\end{tabular}

Standard errors in parentheses.

${ }^{\star} p<0.05,{ }^{* \star} p<0.01,{ }^{\star * \star} p<0.001$

All models are estimated using ordinary least squares, with standard errors robust to firm-level clustering.

Source: Bel-first 2002-2010; Crossroads Bank for Enterprises 
ANNEX A.2

Annex 2. Wage premium

(ref= upper secondary degree) and type of tertiary education degree (Bachelor/Master \& field of study)

Veterinarians
Philosophy, Theology
Architecture
Tourism entertainment

Fine arts (theater, design, music, visual arts)

Acoommodation, restaurant

Teaching (primary kecretary

Teaching (low secondary)

Interior architecture

Media, publicity

Construction, wood

Social assistant

Medical social sciences (nurses)

Other

Ciminology

Languages, Phildogy

Medical assistat

Technician (audio, photo, electricy)

Business assistant (book+keeping, tax, marketing, insurance)

Phamracists

Social Science

Joumelism, translation

Computing IT(A1)

Acoountant

Psychology

Biomecial sciences

Natural sciences (biology, methermetics, chemistry, physics,...

History, History of art, Musioology, Archedlogy

Computing science

Industrial engineers

Medical studies (Physicians, Dentists)

Business

Economios

Civilengineer

Bio enginer, agricultural engineer

Sales engineer

Physical education, physiotherapy, speech therapy

Fine arts (theater, design, music, visual ats)

Philosopty, Theology

History, Histary of art, Musioology, Archedogy

Joumalism trans

Interior architecture

Languages, Philology

Criminology

Social Science

Physical education, physiotherapy, speech therapy

Psychology

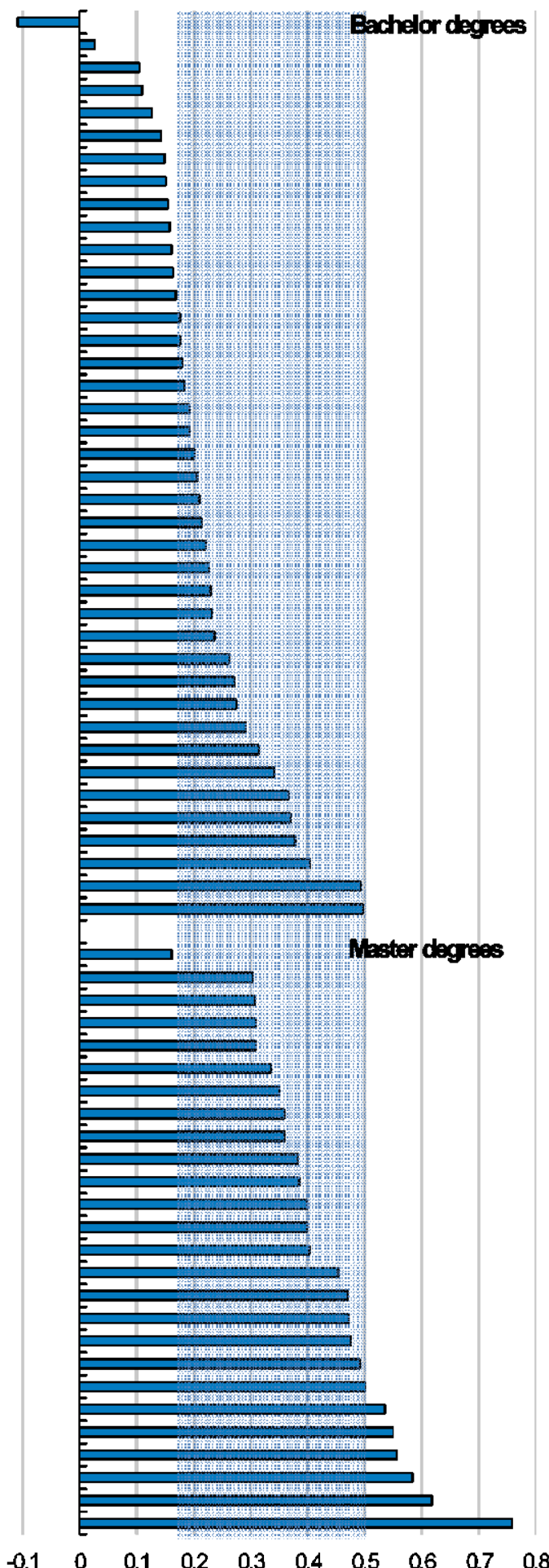

Industrial engineers

Computing science

Natural sciences (biology, mathemetics, chemistry, physics,.

Biometical sconomics

Business

Bio engineer, agricuttural engineer

Sales engineer

Veterinarians

Civil Engineer

Phamecists

Medical studies (Physicians, Dentists)

$\begin{array}{lllllllllll}-0.2 & -0.1 & 0 & 0.1 & 0.2 & 0.3 & 0.4 & 0.5 & 0.6 & 0.7 & 0.8\end{array}$

Note: Marginal effect (in percentage points) on gross earnings per hour of worker holding a tertiary education degree compared to only an upper secondary degree. Estimates control for differences in gender and labour market experience.

Source: Vacature 2008, 2010 \& 2011. 